Changing Societies \& Personalities, 2018

Vol. 2, No. 2, pp. 105-142

http://dx.doi.org/10.15826/csp.2018.2.2.033

ARTICLE

\title{
Socio-Cultural Differences in Social Exclusion
}

\author{
Juan Díez-Nicolás \\ Análisis Sociológicos, Económicos y Políticos and University of Almeria, Spain \\ Ana Maria López-Narbona \\ University of Michigan, USA \\ University of Malaga, Spain
}

\begin{abstract}
The main object of this research is to describe social exclusion in a comparative world perspective. Social exclusion is a main concern worldwide. Non-desirable social groups as neighbours are used as a proxy measure to answer three questions: who are the most excluded social groups, who are the excluders, and what are the main explanatory variables of social exclusion. Social exclusion, as a multidimensional phenomenon, is defined in relation to concepts such as stigma, discrimination, and prejudice. Social, economic, political and ideological-religious attitudes are used to construct the profile of the excluder. Social exclusion has been measured through three indexes of social exclusion, personal, group and total exclusion, since a main component analysis demonstrated that the degree of social exclusion varied depending on whether the excluded group was more or less based on personal decisions on one's behaviour taken by the individual. Based on theory and previous research, four main variables have been tested to explain social exclusion: social position, exposure to information, post-materialist values and perception of security. But other explanatory variables were also added to the analysis. EVS and WVS databases (from 1981 to 2014) have been used, though most of the analysis has been based on the last WVS$6^{\text {th }}$ wave on 59 countries with a total of more than 85,000 interviews.
\end{abstract}

\section{KEYWORDS}

social exclusion, social relations, neighbourhood, indexes, social position, information, post-materialism, security 


\section{Introduction ${ }^{1}$}

Social exclusion has long been a concern for scholars, politicians and citizens. New forms of social exclusion are occurring in the city and at the level of the neighbourhoods such as Gentrification, a social process that was detected in the 60s (Glass, 1964), but which has very recently intensified and produced the "displacement from home and neighbourhood" (Marcuse, 1985).

According to Sassen (2005), "the exclusion of groups of city residents from access to all the city has to offer can be made on the basis of: race, class, religion, income, gender, national origin, sexual orientation or some other characteristic... The restructuring of cities and societies... have led to concerns for the fragmentation of the social world, where some members of society are excluded in the'mainstream' and where this exclusion is painful for the excluded and harmful for society as a whole". However, as suggests Mandanipour (2016), "exclusionary processes per se are not the source of social fragmentation and disintegration. It is the absence of social integration, which causes social exclusion, as individuals do not find the possibility and channels of participating in the mainstream society". In the realm of the neighbourhood, Macy \& Van de Rijt (2006) "proposes that institutional discrimination is not sufficient to explain the persistence of high segregation without the additional assumption that households have a preference for in-group neighbours".

Understanding the causes and conditions of social exclusion in cities and neighbourhoods is critical, as the UN has reckoned that "today, 54 per cent of the world's population lives in urban areas, a proportion that is expected to increase to 66 per cent by 2050". Social relations and social exclusion are mostly produced in urban areas. Segregation, disintegration, marginalization, poverty and criminality produce and are reproduced by social exclusion provoking a breakdown of social order.

The aim of this paper is to analyse social exclusion at the level of the neighbourhood as "it is important to know what are the forces, which tend to break up the tensions, interests, and sentiments which give neighbourhoods their individual character" (Park, 1984). Three main questions are posed to address this issue: Who is subject of social exclusion in neighbourhoods? Who is the actor of social exclusion in neighbourhoods? What are the factors that explain social exclusion in neighbourhoods? There are independent intra and extra-neighbourhood effects on individuals' behaviours that should be further analysed in order to properly understand the process of social exclusion in neighbourhoods.

Neighbourhoods are privileged places to research social exclusion. Life develops mostly in neighbourhoods where people meet, disagree, and reunite in contiguity, intimacy and vicinity. "Proximity and neighbourly contact are the basis for the simplest and most elementary form of association with which we have to do in the organization of city life" (Parks, 1984). Neighbourhoods are poles of attraction for groups of people with differential characteristics. Society may be divided into smaller

${ }^{1}$ A first version of this paper was presented at the WAPOR Annual Conference, Lisbon, Portugal, 15-17 July 2017. Similar versions have also been presented at the University of Almeria 19-20 October 2017 and the University of Granada 20 February 2018. 
units until reaching the level of the neighbourhood without losing the essence of society as "the neighbourhood is a social unit which, by its clear definition of outline, its inner organic completeness, its hair-trigger reactions, may be fairly considered as functioning like a social mind" (Woods, 1913).

Individuals in society can only be understood as processes in the confluence of time, space and place. In the same sense, neighbourhoods are spatially and timely based. Perception of the neighbourhood boundaries is variable and their design is arbitrarily drawn. For Glaster (2001), "certain topographical features are permanent. Sewer infrastructures and buildings last typically generations. Others, such as tax/public service packages and demographic and status profiles of an area, can change over a year. The area's social interrelationships can be altered even more rapidly". Moreover, as Burgess (1984) suggests "boundaries of local areas determined ecologically, culturally, and politically seldom, if ever, exactly coincide".

Cities and neighbourhoods provide the opportunity to analyse micro-social processes (social relationships), the results of which can be extrapolated to macro-social processes that take place in larger urban spaces and societies. Sassen (2005) suggests that "the city has long been a site for the exploration of major subjects confronting society and the social sciences. In the mid 1990s, it lost that heuristic capability. Today the city is once again emerging as a strategic lens for producing critical knowledge, not only about the urban condition but also about major social, economic, and cultural refiguring in our societies". We understand neighbourhoods as concrete space, time and places where social exclusion occurs. Therefore, connecting social exclusion with cities and neighbourhoods may contribute to identify divisions in order to look for cohesion, to give new sense to long defended rights such as social citizenship and social justice, and to cope with social processes that are pressing problems in worldwide cities such as gentrification, parochialism, segregation, marginalization and purification.

Social exclusion has many dimensions like impoverishment, labour market exclusion, service exclusion, and exclusion from social relations, among others. The present study, however, is specifically designed to measure social exclusion from social relations using the World Values Survey ${ }^{2}$ (hereinafter WVS) variables 36 to 44 (which pose the questions: "Would not like to have as neighbours...") as a proxy measure. In the context of residential segregation, Clark $(1986,2006)$ suggests that prejudice is equated to "would not like..." Groups proposed in WVS questions refer to social exclusion from social relations (social avoidance and social distance) in neighbourhoods. The present analysis is structured in six sections.

Section 2 focuses on the main concepts and theories in which the research developed in this paper is based. We address the concept of social exclusion and the concepts closely related to it. The specialised literature has developed different models to explain different categories of social exclusion from social relations. Models of prejudice mostly focus on issues of race, ethnicity and immigration. Models of stigma relate to deviant behaviour and identities, and disease and disabilities. Social

${ }^{2}$ Most of the analysis has been based on the data set of the WVS-6 ${ }^{\text {th }}$ wave, 2010-2014, which includes 59 countries with a total of more than 85,000 personal interviews, mostly face-to-face. But some analysis have used the combined data set EVS-WVS 1981-2014, which includes six waves (1981, 1990, $1995,2000,2005$ and 2010), 110 countries and a total of 506,487 personal interviews. 
exclusion, stigma, prejudice and discrimination are concepts closely interrelated. More recently some scholars have developed ethnic preferences models which propose the hypothesis that social distance and preference dynamics could generate and sustain significant levels of segregation in the absence of discrimination (Clark, 2006; Fosset, 2006, 2011). In order to understand what generates social exclusion in neighbourhoods, we carry out a literature review.

Sections 3 to 6 are directed to the empirical analysis of social exclusion in neighbourhoods using the already mentioned question as to persons or groups that would not be accepted as neighbours. To address the statistical analysis, some questions are posed:

a) who is the subject of social exclusion in neighbourhoods? (Sections 3: Describing who are the Excluded social groups, and Section 4: Construction of Social Exclusion Indexes);

b) who is the actor of social exclusion in neighbourhoods? (Section 5: Describing the Excluders);

c) what are the main factors that explain social exclusion in neighbourhoods? Which are the causes and conditions of social exclusion? (Section 6: Explaining Social Exclusion).

The first question tries to determine the main characteristics of the persons subject to social exclusion. We consider that the excluded is objectified, commoditised, standardized, homogenized, equalized, and grouped; in sum, people who suffer social exclusion lose their private and own characteristics as individual persons and become part of a category that elicits social exclusion. The second question addresses the socio-demographic profile of the excluder. Although there are important methodological differences in measuring attitudes, opinions and behaviours, the questions posed by the WVS concerning neighbours will help us to design an image of the person who manifests his or her exclusion to others.

With the third question, we look for causes and conditions of social exclusion. Many reflections arise on this point. First, can we sustain that there is a globalization of attitudes? Second, as Allport (1954) and others suggest, it is very likely that the person or group that shows prejudice or discrimination against one group, also shows discrimination or prejudice against more groups. Can we apply this conclusion to our statistical analysis? Third, can we extrapolate the meso-social level analysis (neighbourhoods) to the macro-social level (society), or the manifestations of prejudice, discrimination and social exclusion are different at different levels of analysis? How can the Bogardus social distance scale be applied in our statistical analysis? Fourth, we have divided the WVS variables used in this research into two groups, Personal Exclusion (mainly referred to voluntary generally nonaccepted social behaviours of individual persons like heavy drinkers, drug-addicts, homosexuals...) and Group Exclusion (referred to social exclusion based on racism and xenophobia which implies exclusion based on the belonging to racial, ethnic and foreign groups), which of the two groups of variables attract the more prejudice, stigma and discrimination, in sum, social exclusion? In the case that it is Personal Exclusion, do people blame individual persons for these behaviours? Do excluders 
consider that excluded's behaviour is voluntary and could and should be controlled? In the case of Group Exclusion, is blaming out of the question? What would be the main reasons for this kind of social exclusion?

The last section, Section 7, contains the main Conclusions and Discussions on the topics analysed.

\section{The Process of Social Exclusion}

Social exclusion is closely related to, but should be distinguished from, concepts such as stigma, prejudice, discrimination, poverty, deprivation, and inequality, although the conceptual distinction is not an easy task. In the following lines, we expose different definitions and conceptualisations of the main terms above mentioned and their relation to social exclusion. Stigma, prejudice and discrimination models have been used to explain social exclusion. Further to these models, scholars after Schelling (1971) are focusing their interest in the preferences and social distance models posing the following question: is social exclusion always based on any kind of rejection of the other, be it stigma, prejudice, stereotyping or discrimination? This question is addressed from a theoretical perspective. We finish with a literature review on the concept of social exclusion and its connections to social relations, social distance and neighbourhood.

\section{Stigma}

The concepts of social exclusion and stigma are interrelated. Goffman (1963) suggested that people who possess a characteristic defined as socially undesirable acquire a spoiled identity, which then leads to social devaluation and discrimination. However, according to Deacon, Stephney \& Prosalendis (2005), social stigma does not always produce discrimination.

Stigma is a mark or sign of disgrace usually eliciting negative attitudes to its bearer. If attached to a person with a mental disorder (heavy-drinkers or drugaddicts) it can lead to negative discrimination. It is sometimes but not always related to a lack of knowledge about the condition that led to stigmatisation. Stigma can therefore be seen as an overarching term that contains three elements: problems of knowledge (ignorance), problems of attitudes (prejudice), and problems of behaviour (discrimination). Stigma is then related not only to social exclusion but also to ignorance, prejudice and discrimination.

\section{Prejudice}

Prejudice is also a concept intimately related to social exclusion. Allport (1954) argued that prejudice is an "antipathy based upon a faulty and inflexible generalization". Therefore, according to Allport, prejudices are negative attitudes towards groups and individuals based solely on their group membership. Allport (1954) also suggested that "one of the facts of which we are most certain is that people who reject one out-group will tend to reject other out-groups. If a person is anti-Jewish, he is likely to be anti-Catholic, anti-Negro, anti any out-group". Adorno 
et al. (1950) demonstrated that authoritarianism is associated with prejudices against many different groups.

According to Elliot et al. (1982), once a person has been classified (through stigma or prejudice) as illegitimate for participation in an interaction, he or she is beyond the protection of social norms and, as such, may be excluded or ignored altogether.

For Joffe (1999), stigma and prejudice would be fundamental emotional responses to danger that help people feel safer by projecting controllable risk, and therefore blame, onto out groups. These socially constructed representations only result in discrimination and the reproduction of structural inequalities when other enabling circumstances (such as power and opportunity to discriminate) come into play. Phelan, Link, and Dovidio (2008) explored commonalities and possible distinctions between prejudice and stigma, concluding that most differences are a matter of focus and emphasis. One important distinction is in the type of human characteristics that are the primary focus of models of prejudice (race) and stigma (deviant behaviour and identities, and disease and disabilities) which allowed them to develop a typology of three functions of stigma and prejudice: exploitation and domination (keeping people down); norm enforcement (keeping people in); and disease avoidance (keeping people away).

\section{Discrimination}

Parker and Aggleton (2003) consider that stigma and discrimination should be understood as part of the political economy of social exclusion present in the contemporary world. The three concepts then are closely interrelated and cannot be conceptualised independently. Discrimination can be seen as the behavioural consequence of stigma, which acts to the disadvantage of people who are stigmatised (Sayce, 2000). The rejecting behaviour of others may bring greater disadvantage than the primary condition itself.

Conceptualisations of the terms referring to rejection of the other have their foundation on the point of view of the actor, i.e., the person or group of persons who stigmatise, discriminate and exclude. For Zick et al (2011), "individuals are looked down upon not on the basis of their personal characteristics but through nothing other than their categorization as a member of an out-group. It is utterly irrelevant whether they see themselves as a member of this group or whether their group membership can be determined objectively. What matters is solely the categorization by the person holding or expressing the prejudice".

There are many scholars who advocate for definitions that take into account the point of view of the stigmatised because the way they respond to stigma can materially affect the impact of stigma in society, whatever the extent of actual discrimination based on stigma (Deacon, Stephney \& Prosalendis, 2005).

\section{Social exclusion}

The concept of social exclusion was developed in France in 1974 to refer to groups, "les exclus", with no access to the labour market and with limited or not recognized 
rights to social citizenship. However, rejection or social exclusion has existed along human history. In the Ancient Greece, ostracism was used to eliminate men seen as a threat to the state (Figueira, 1987). According to Forsdyke (2000), the creation of the institution of ostracism, whereby the people decided collectively whether to banish a single citizen for ten years, provided not only a mechanism for the symbolic expression of democratic power, but also a means for the practical and ideological distinction between oligarchic and democratic rule. The infrequent and moderate use of exile as a means of resolving political conflict helps to explain the extraordinary stability of the Athenian democracy.

From a Durkheimian point of view, social exclusion is functional for society as it helps to establish moral, legal and cultural limits of society and to give stability to the status quo. Christianity applies a similar institution called ex-communion (Eliade, 1961; De la Garza \& Valdes, 1998). Sen (1992) highlights the lack of capabilities as the key component of the exclusion process. Socially excluded individuals are denied access to the resources (material, cultural, emotional) that enable them to acquire capabilities related to cognitive development and educational success, but also extend to the broader spheres of health and social participation.

According to Rodgers (1995), "exclusion is an evolving pattern that encompasses all facets of an individual's life". For Room (1992, 1995), the main aspects of the concept of social exclusion are "multidimensionality, dynamicity and relationality". Multidimensionality refers to different dimensions of social exclusion (social, economic, cultural, political) and different levels (micro, i.e., individual, household; meso, i.e., neighbourhoods; and macro, i.e., nation state and global regions) along a social exclusion/inclusion continuum; dynamicity implies that social exclusion impacts in different ways to differing degrees at different social levels over time; and relationality (Room, 1995) because it focuses on exclusion as the rupture (or inequality) of relationships between people and society resulting in a lack (or differential) of social participation, social protection, social integration and power.

Levitas (2005) defines social exclusion as "the dynamic process of being shut out, fully or partially, from any of the social, economic, political, cultural systems, which determine the social integration of a person in society". Social exclusion used in this research is conceptualised as the process of rejection of a group or a person, in any degree, that keep the rejected group or person out from the social system based on stigma, prejudice, stereotyping and/or discrimination. The main foundations of rejection would be fear, ignorance, blaming, social control, and avoidance of risk.

\section{Ethnic preferences and social distance}

Attitude and social distance surveys usually ask what they would do in imaginary situations or what they think most people would do, for example, when faced with a neighbour or work colleague with mental illness. This work has emphasised what normal people say without exploring the actual experiences of people with mental illness themselves about the behaviour of normal people toward them. Further, it has been assumed that such statements (usually on knowledge, attitudes or behavioural intentions) are congruent with actual behaviour, without assessing such behaviour 
directly. Such research has generally focused on hypothetical rather than real situations, neglecting emotions and the social context, thus producing very little guidance about interventions that could reduce social rejection.

Bogardus' Social Distance Scale scores ranged from one to seven along a choice continuum in which there is a category regarding neighbours. Its influence is still high despite discrepancies between expressed attitudes and actions. A Reverse Social Distance Scale (Guttman's coefficient of reproducibility) was created to measure minority groups' perceptions of the social distance. Schelling (1971) analysed why groups cluster together in residential neighbourhoods. Small differences in the preference of an individual to be with others of a similar type (ethnicity, e.g.), could lead to quite distinct patterns of separation in the population. For Schelling, microlevel voluntary choices and economic competition can create or maintain macro-level patterns of residential segregation along ethnic and socio-economic dimensions.

Urban-ecological studies of residential segregation try to understand the "urban mosaic", i.e., the complex differentiation of residential neighbourhoods that stands as a fundamental fact of urban life (Fosset, 2011). Segregation occurs along many axes, race, ethnicity, socioeconomic position, age, stage of family life cycle, nativity, and life style producing a highly variegated urban spatial fabric. According to Fosset (2006) many factors contribute to ethnic segregation such as discrimination. However, as past forms of discrimination slowly fade, it is compulsory to direct special attention to the role of ethnic preferences and social distance dynamics associated with in-group attraction and out-group avoidance.

Discrimination alone is insufficient to account for the extent and continuing nature of residential separation and segregation, as the explanation is multidimensional (Clark, 1986, 2006). Social preferences (ethnocentrism or in-group preferences) appear as a factor to take into account together with economic status (affordability), urban structure, and discrimination.

In the following lines, we address the three main questions proposed to analytically unravel the process of social exclusion in neighbourhoods. First, who is the person subject to social exclusion, i.e., who is the excluded? Second, who is the actor of social exclusion, i.e., who is the excluder? In the model proposed in this work, the actor of social exclusion cannot be understood without the person subject to social exclusion. Third, why and how is there social exclusion, i.e., which are the causes and conditions of social exclusion?

The point of view exposed in this work is the point of view of the actor, i.e., of the person who answers to the question posed in the WVS: "Would not like to have as neighbours..." The analysis of social exclusion is then inferred indirectly through the answers to questions posed in a negative form ("Would not like to have as neighbours...").

Although there are some limitations of applying a concept (social exclusion) developed in the industrialised countries with welfare systems, to nation states with weak governance, minimal welfare provision, and a majority of the population living in extreme poverty, in this research we will do some inferences to the main world cultural regions using data from the WVS. 


\section{Measuring Social Exclusion in a Comparative Frame. Who are the Excluded Groups?}

Social exclusion, as measured by the proxy indicator already mentioned, social groups not wanted as neighbours, depends obviously on the social groups listed and presented to the respondents. Values surveys have included this question since the first EVS-WVS wave in 1981, and have continued to include it in all WVS waves in 1990, 1995, 2000, 2005 and 2010, but the target groups of the question have varied in time. In Table 1 we have listed the social groups that have been included in the last completed WVS wave (2010-2014) in order to compare with previous waves. In the first column the aggregate summary for all waves is presented, but in the other columns social groups mentioned in each wave as "not wanted as neighbours" are listed.

Table 1

Percentage That Would Not Like Different Social Groups as Neighbours, WVS-EVS 1981-2014, by Wave

\begin{tabular}{lr|r|r|r|r|r|r}
\hline \multicolumn{1}{c}{ Social groups } & $\begin{array}{r}\text { All waves } \\
\text { 1981-2014 }\end{array}$ & 1981 & 1990 & 1995 & 2000 & 2005 & 2010 \\
\hline Drug addicts & $\mathbf{6 5 . 1}$ & - & 62 & 67 & 66 & 73 & 79 \\
Heavy drinkers & $\mathbf{5 8 . 4}$ & 48 & 56 & 59 & 55 & 60 & 65 \\
Homosexuals & $\mathbf{4 1 . 0}$ & - & 44 & 43 & 42 & 43 & 47 \\
People with AIDS & $\mathbf{3 6 . 3}$ & - & 40 & 38 & 39 & 35 & 41 \\
Unmarried Couples & $\mathbf{7 . 5}$ & - & - & - & - & 19 & 25 \\
Immigrants & $\mathbf{1 8 . 6}$ & 6 & 16 & 15 & 21 & 19 & 25 \\
Different Religion & $\mathbf{8 . 0}$ & - & - & 3 & 6 & 15 & 19 \\
Different Race & $\mathbf{1 5 . 3}$ & $\mathbf{8}$ & 15 & 12 & 18 & 15 & 19 \\
Different Language & $\mathbf{4 . 9}$ & - & - & - & - & 12 & 17 \\
No. of Data sets & $\mathbf{3 3 1}$ & 24 & 43 & 67 & 79 & 58 & 60 \\
No. of Respondents & $\mathbf{( 5 0 6 , 4 8 7 )}(29,685)$ & $(62,769)$ & $(118,253)$ & $(125,531)$ & $(83,975)$ & $(86,274)$ \\
\hline
\end{tabular}

In the EVS-WVS 1981 wave only three groups of those included in the last WVS wave (2010) were also included. It must be underlined the high stability of proportions of the total population that reject the same social groups. It is also a surprising finding that there seems to be a certain tendency to higher rather than lower proportions of rejection of the same social groups. Thus, the proportion that would not want as neighbours each of these nine social groups in the last wave, 2010-2014, is in all cases the highest of the total period. The larger increases in absolute terms correspond to the rejection of Immigrants and Foreign workers, Drug addicts and Heavy drinkers, and to a lesser degree, people of a different Race.

We think that every social fact must be interpreted in space and time, and in this case it must be taken into account that the last WVS wave was conducted in the period when the financial and economic crisis that began in 2007 was at its very peak. Fears and worries of populations around the world might explain the growth of social exclusion of all social groups. Another factor might be that in the last wave there have been a few more developed countries and an increase of less developed countries, and also an increase of MENA region countries. 
Percentage That Would Not Like Different Social Groups as Neighbours,

by Geo-Cultural Regions and Russia, WVS-6 (2010-2014)

\begin{tabular}{|c|c|c|c|c|c|c|c|c|c|c|c|c|c|c|c|c|c|}
\hline \multicolumn{2}{|c|}{ All countries } & \multicolumn{2}{|c|}{ Anglo-Saxon } & \multicolumn{2}{|c|}{$\begin{array}{l}\text { European } \\
\text { Union }\end{array}$} & \multicolumn{2}{|c|}{$\begin{array}{c}\text { East Europe \& } \\
\text { Balkans }\end{array}$} & \multicolumn{2}{|c|}{ MENA } & \multicolumn{2}{|l|}{ Asia } & \multicolumn{2}{|c|}{ Latin America } & \multicolumn{2}{|c|}{ Sub-Sahara } & \multicolumn{2}{|c|}{ Russia } \\
\hline $\begin{array}{l}\text { Drug } \\
\text { addicts }\end{array}$ & 78.5 & $\begin{array}{l}\text { Drug } \\
\text { addicts }\end{array}$ & 89.6 & $\begin{array}{l}\text { Drug } \\
\text { addicts }\end{array}$ & 77.1 & $\begin{array}{l}\text { Drug } \\
\text { addicts }\end{array}$ & 93.9 & $\begin{array}{l}\text { Drug } \\
\text { addicts }\end{array}$ & 75.7 & $\begin{array}{l}\text { Drug } \\
\text { addicts }\end{array}$ & 70.4 & $\begin{array}{l}\text { Drug } \\
\text { addicts }\end{array}$ & 72.4 & $\begin{array}{l}\text { Drug } \\
\text { addicts }\end{array}$ & 82.2 & $\begin{array}{l}\text { Drug } \\
\text { addicts }\end{array}$ & 93.2 \\
\hline Drinkers & 65.0 & Drinkers & 70.0 & Drinkers & 68.3 & Drinkers & 85.1 & Drinkers & 66.4 & Drinkers & 57.6 & Drinkers & 51.3 & $\begin{array}{l}\text { Homo- } \\
\text { sexuals }\end{array}$ & 66.0 & Drinkers & 84.3 \\
\hline $\begin{array}{l}\text { Homo- } \\
\text { sexuals }\end{array}$ & 46.6 & $\begin{array}{l}\text { Homo- } \\
\text { sexuals }\end{array}$ & 17.1 & $\begin{array}{l}\text { Homo- } \\
\text { sexuals }\end{array}$ & 27.0 & $\begin{array}{l}\text { Homo- } \\
\text { sexuals }\end{array}$ & 73.2 & $\begin{array}{l}\text { Homo- } \\
\text { sexuals }\end{array}$ & 57.7 & AIDS & 49.0 & $\begin{array}{l}\text { Homo- } \\
\text { sexuals }\end{array}$ & 27.1 & Drinkers & 59.7 & $\begin{array}{l}\text { Homo- } \\
\text { sexuals }\end{array}$ & 66.2 \\
\hline AIDS & 40.4 & AIDS & 14.6 & AIDS & 25.2 & AIDS & 67.0 & AIDS & 55.5 & $\begin{array}{l}\text { Homo- } \\
\text { sexuals }\end{array}$ & 39.6 & AIDS & 17.4 & $\begin{array}{l}\text { Immi- } \\
\text { grants }\end{array}$ & 24.3 & AIDS & 54.3 \\
\hline Couples & 25.2 & $\begin{array}{l}\text { Immi- } \\
\text { grants }\end{array}$ & 11.2 & $\begin{array}{l}\text { Immi- } \\
\text { grants }\end{array}$ & 19.4 & $\begin{array}{l}\text { Immi- } \\
\text { grants }\end{array}$ & 27.0 & Couples & 54.1 & $\begin{array}{l}\text { Immi- } \\
\text { grants }\end{array}$ & 33.7 & Language & 10.4 & AIDS & 23.0 & $\begin{array}{l}\text { Immi- } \\
\text { grants }\end{array}$ & 32.2 \\
\hline $\begin{array}{l}\text { Immi- } \\
\text { grants }\end{array}$ & 24.8 & Language & 10.5 & Race & 13.8 & Couples & 25.0 & $\begin{array}{l}\text { Immi- } \\
\text { grants }\end{array}$ & 32.3 & Couples & 28.1 & Religion & 10.0 & Couples & 20.0 & Language & 18.9 \\
\hline Religion & 19.2 & Race & 4.9 & Religion & 11.0 & Race & 22.8 & Religion & 30.4 & Religion & 23.6 & $\begin{array}{l}\text { Immi- } \\
\text { grants }\end{array}$ & 9.4 & Religion & 15.8 & Race & 17.2 \\
\hline Race & 18.7 & Couples & 4.2 & Language & 10.9 & Religion & 22.7 & Race & 28.1 & Race & 22.3 & Race & 7.9 & Race & 15.5 & Religion & 14.3 \\
\hline Language & 17.3 & Religion & 3.2 & Couples & 7.4 & Language & 16.7 & Language & 25.1 & Language & 21.8 & Couples & 7.8 & Language & 15.3 & Couples & 7.8 \\
\hline
\end{tabular}


Since there seems to be a high stability of exclusionist attitudes, especially regarding the rank order of groups (it has been the same in all six waves, without a single exception), we have focused on the data of the last WVS wave, 2010-2014 ${ }^{3}$. To that effect we have grouped the 59 countries in only seven geo-cultural regions ${ }^{4}$. Throughout this article, we have always considered Russia as a separate unit of analysis for comparative purposes.

Drug addicts are unanimously the most rejected social group as neighbours, with no exceptions. The second most rejected social group is heavy drinkers, with the only exception of Sub-Saharan countries. The reason is that homosexuals are much more excluded in those countries, being the second most rejected social group in that world region. The rejection of heavy drinkers is lowest in Latin America (51\%) and highest in East Europe and the Balkans (85\%), and not in MENA countries (66\%), as one might have expected because of religious norms.

The third most rejected social group is that of homosexuals, but with two exceptions, Sub-Sahara, where they are the second most rejected group, and Asia, where they are less rejected than people with AIDS. Rejection of homosexuals as neighbours shows a very high variation, so that the least exclusion is observed in Anglo-Saxon countries (17\%) and the highest in East Europe and the Balkans (73\%).

Other findings that deserve some underlining are the higher exclusion of people with AIDS in East Europe and the Balkans and in MENA region countries (67\% and $56 \%$ respectively), the higher rejection of unmarried couples in MENA region (54\%), the higher exclusion of immigrants and foreign workers in Asia and MENA regions (34\% and $32 \%$ respectively), and the higher exclusion of people of a different religion, a different race and a different language in MENA region countries $(30 \%, 28 \%$ and $25 \%$ respectively).

Social groups that seem to be more rejected in general are those based on some personal, rather than group, characteristic. Does it mean that people are more tolerant with individuals who are different because they belong to a group regardless of their choice (i.e., different race) than with those who apparently belong because having made a personal choice (i.e., heavy drinkers)?

\footnotetext{
${ }^{3}$ Data sets are usually equivalent to countries, but not always, because in some cases there are two or more data sets for a country (i.e., East and West Germany). Besides, while WVS has conducted surveys in all six waves, EVS has conducted its waves only in 1981, 1990, 1999 and 2008. These data sets have been included in the nearest WVS wave date. Furthermore, some countries have participated in the WVS and the EVS with the same or different teams, as is the case for Spain, Sweden, Turkey and other countries. That is why datasets and countries not always are the same. In the last WVS wave there were 59 countries but 61 datasets.

${ }^{4}$ The distribution of countries by geo-cultural regions is as follows: Anglo-Saxon (Australia, New Zealand, and United States), European Union (Cyprus, Estonia, Germany, Netherlands, Poland, Romania, Slovenia, Spain, and Sweden), East Europe and the Balkans (Armenia, Azerbaijan, Belarus, Kazakhstan, Kyrgyzstan, Russia, Ukraine, and Uzbekistan), MENA (Algeria, Bahrain, Egypt, Iraq, Jordan, Kuwait, Lebanon, Libya, Morocco, Palestine, Qatar, Tunisia, Turkey, and Yemen), Asia (China, Hong Kong, India, Japan, Malaysia, Pakistan, Philippines, Singapore, South Korea, Taiwan, and Thailand), Latin America (Argentina, Brazil, Chile, Colombia, Ecuador, Mexico, Peru, Trinidad and Tobago, and Uruguay), SubSaharan Africa (Ghana, Nigeria, Rwanda, South Africa, and Zimbabwe).
} 
Table 3

Percentage That Would Not Like Different Social Groups as Neighbours, Russia 1990-2010, by Wave

\begin{tabular}{lr|rr|rrr|r}
\hline \multicolumn{1}{c}{ Social groups } & 1990 & \multicolumn{2}{c|}{1995} & 2000 & 2005 & 2010 \\
\hline Drug addicts & 86 & 86 & 85 & 94 & 93 \\
Heavy drinkers & 82 & 76 & 78 & 89 & 84 \\
Homosexuals & 81 & 64 & 61 & 66 & 66 \\
AIDS & 68 & 54 & 55 & 58 & 54 \\
Immigrants & 12 & 11 & 31 & 32 & 32 \\
Race & 11 & - & - & 16 & 17 & 17 \\
Religion & - & - & - & 16 & 14 \\
Language & - & - & - & 14 & 19 \\
Couples & - & - & - & 4 & 8 \\
\hline
\end{tabular}

In general, drug addicts, heavy drinkers, homosexuals, and people with AIDS seem to be more rejected than unmarried couples or people who are immigrants, or of a different religion, race or language. In general, East Europe and the Balkans, together with MENA countries, are usually the regions where almost all mentioned social groups seem to be more undesired as neighbours.

Regarding Russia, drug addicts and heavy drinkers are certainly not desired as neighbours by almost unanimity of respondents, and rejection has increased in the past two waves. Homosexuals are excluded by almost two thirds of respondents since 1995, though a little less than they were in 1990. Social exclusion of people with AIDS has decreased, but rejection of immigrants, people of a different race, of a different language and of unmarried couples, has increased, though their social exclusion is still very low, as that of people of a different religion. The general pattern of social exclusion in Russia, according to last wave results, is very similar to the group of countries in East Europe and the Balkans, with the only exception of the social exclusion of people of a different language, relatively much higher in Russia than in East Europe and the Balkans.

As mentioned, persons who discriminate some social groups are more likely to discriminate others. For that reason, and with the objective of constructing an index of social exclusion, some models of principal component analysis have been calculated. This analysis, allowing for the free selection of components, shows that there are two principal components, one composed of five items and another one composed of four items. In the first component we find four items with saturations above .650 and one with a lower saturation of .573 (unmarried couples living together). It seemed advisable to eliminate this item, since it does not seem to belong to either component. The second component also includes four items. Thus, the four items in the first component seem to imply that respondents consider that the individual belongs to each of the four social groups (people of a different race, religion, language and immigrants) because of its belonging to it is not dependent of a specific behaviour, while the four items included in the second component (drug addicts, heavy drinkers, people with AIDS and homosexuals) seem to depend, at least partially, on personal decisions and/or behaviours. This, at least, seems to be 
the perspective that respondents may have, whether or not it is correct. In any case, we have computed a second principal component analysis with free selection of components but excluding unmarried couples living together.

Table 4

Main Component Analysis with Items Regarding Social Exclusion (Excluding Unmarried Couples Living Together) (Free Number of Components), Full Sample WVS-6 (2010-2014)

\begin{tabular}{l|c|c}
\hline \multirow{2}{*}{ Social groups } & \multicolumn{3}{c}{ Rotated Component Matrixa } \\
\cline { 2 - 3 } & \multicolumn{3}{c}{ Component } \\
\cline { 2 - 3 } & 1 & 2 \\
\hline Drug addicts & -.209 & .751 \\
People of a different race & .776 & .037 \\
People who have AIDS & .392 & .595 \\
Immigrants/foreign workers & .672 & .155 \\
Homosexuals & .269 & .631 \\
People of a different religion & .753 & .035 \\
Heavy drinkers & -.052 & .743 \\
People who speak a different language & .743 & -.046 \\
\hline
\end{tabular}

Extraction Method: Principal Component Analysis. Rotation Method: Varimax with Kaiser Normalization. a. Rotation converged in 3 iterations.

Similar principal component analyses have been calculated for the seven regions, producing similar but no exactly equal distribution of items in two components. The first component is clearly found with the same items and high saturations in five regions (and in Russia), but not in the MENA region or in Asia. In these two regions the same four items, with high saturations, are found in the second component. But the other four items (drug addicts, heavy drinkers, homosexuals and people with AIDS), whether in the first or the second component, show a more irregular pattern.

Thus, in Anglo-Saxon countries two items (people with AIDS and homosexuals) make the second component, but drug addicts and heavy drinkers are part of a third component, all with very high saturations. In the MENA region and Asia the four items make the first component, with high saturations. In East Europe and the Balkans the four items are part of the second component, with high saturations, like in the total sample of 59 countries. In Latin America and Sub-Saharan Africa the second component has only three items (drug addicts, heavy drinkers and homosexuals), but people with AIDS shows a low saturation and is not part of any component. In the European Union only two items are part of the second component, drug addicts and heavy drinkers, but both homosexuals and people with AIDS are not part of any component because of low saturations. And in Russia the second component includes drug addicts, as well as heavy drinkers, people with AIDS and homosexuals.

A final principal component analysis has been produced, asking for only one component, so that all eight items would rank themselves according to their saturation. Results mean that a person that wouldn't like people of a different race as neighbours is very likely to dislike other social groups too, while those who reject drug addicts may or may not reject members of other social groups. 


$\begin{gathered}\text { Main Component Analysis with Items Regarding Social Exclus } \\
\text { (Excluding Unmarried Couples Living Together) (One Component R } \\
\text { Full Sample WVS-6 (2010-2014) }\end{gathered}$
\begin{tabular}{l|c}
\hline \multicolumn{1}{c}{ Social groups } & Component 1 \\
\hline People of a different race & .718 \\
People of a different religion & .696 \\
Immigrants/foreign workers & .674 \\
People who speak a different language & .653 \\
People who have AIDS & .608 \\
Homosexuals & .512 \\
Heavy drinkers & .270 \\
Drug addicts & .131 \\
\hline
\end{tabular}

Table 5

Extraction Method: Principal Component Analysis. a. 1 component extracted

As this analysis demonstrates once more, all four of the more "personal" items show the lowest saturations, while all four of the more "group" items show the highest saturations. The same analysis for Russia is very similar, the items with the highest saturation are race, immigrants and language, while the two with the lowest saturation are drug addicts and heavy drinkers, in that order.

\section{Construction of Social Exclusion Indexes}

On the basis of these eight items, therefore, we have constructed three social exclusion indexes: a Personal Exclusion Index, a Group Exclusion Index and a Total Exclusion Index.

Total Exclusion Index has been constructed by adding the number of social groups that each respondent mentioned as not wanted neighbours. Consequently, since there were eight social groups for which the question was posed, the index could vary from 0 (no social group was mentioned at all as not wanted), to 8 (all social groups were mentioned as not wanted as neighbours). Only $9 \%$ of the total sample did not mention any social group as undesired neighbours, and less than half that proportion (4\%) answered that they did not want as neighbours people belonging to each one of the eight social groups for which the question was posed.

The mean number of undesired social groups for the total sample was 3.11 , with a standard deviation a little over half the mean. The highest number of social groups excluded is found in East Europe and Balkan countries, and also in the MENA region countries, while the lowest index is found in Latin America, Anglo-Saxon and European Union countries. But the highest dispersion of social exclusion is found in Latin America and in the European Union countries, while the lowest coefficient of variation is found in East European and Balkan countries ${ }^{5}$.

${ }^{5}$ The coefficient of variation (CV) is the ratio between the standard deviation over the mean, as a percentage to standardize the measure. The higher the CV the greater seems to be the variation in the number of social groups excluded by the respondents in the population, while a lower CV means that there is a high agreement among respondents in the number of social groups undesired as neighbours. 
Table 6

Mean and Standard Deviation in Total Social Exclusion Index by Geo-Cultural Regions and Russia (Mean Number of Social Groups Excluded as Neighbours), WVS-6 (2010-2014)

\begin{tabular}{l|r|r|c|c|r|r|r|r|r}
\hline $\begin{array}{c}\text { Mean } \\
\text { and } \\
\begin{array}{c}\text { Standard } \\
\text { Deviation }\end{array}\end{array}$ & $\begin{array}{c}\text { All } \\
\text { countries }\end{array}$ & $\begin{array}{c}\text { Anglo- } \\
\text { Saxon }\end{array}$ & $\begin{array}{c}\text { European } \\
\text { Union }\end{array}$ & $\begin{array}{c}\text { Tast } \\
\text { Europe \& } \\
\text { Balkans }\end{array}$ & MENA & Asia & $\begin{array}{c}\text { Latin } \\
\text { America }\end{array}$ & $\begin{array}{c}\text { Sub- } \\
\text { Sahara }\end{array}$ & Russia \\
\hline$\overline{\mathrm{x}}$ & $\mathbf{3 . 1 1}$ & 2.11 & 2.53 & 4.08 & 3.71 & 3.18 & 2.06 & 3.02 & $\mathbf{3 . 8 1}$ \\
$\sigma$ & $\mathbf{1 . 9 6}$ & 1.27 & 1.80 & 1.73 & 2.22 & 1.99 & 1.58 & 1.42 & $\mathbf{1 . 7 2}$ \\
$\mathrm{CV}$ in \% & $\mathbf{6 3 . 0 0}$ & 60.20 & 71.20 & 42.40 & 59.80 & 62.60 & 76.70 & 47.00 & $\mathbf{4 5 . 1 0}$ \\
\hline
\end{tabular}

In sum, people in East European and Balkan countries and in MENA region countries seem to exclude more social groups as neighbours, and they show the highest consensus on their populations regarding that measure of social exclusion, while people in Latin America and European Union countries show the lowest total social exclusion but with the highest variation in the number of excluded social groups in their populations.

And, coherent with the data already examined above, Russia shows a very high index of total social exclusion (only lower than in the East Europe and Balkan region), but with a low coefficient of variation (small differences among those who exclude many social groups and those who exclude very few, meaning a high consensus in the population). We will examine later what factors explain the great variation in total social exclusion in Latin American and European Union countries, though they are the countries with the lowest total social exclusion as measured by the question about undesired neighbours used as proxy.

We have constructed two more social exclusion indexes, taking into consideration the findings from the principal component analysis mentioned before. Principal component analysis showed, not only for the total sample of 59 countries, but also for most of the seven geo-cultural regions, that there were two main components, one grouping four of the social groups in a component that seemed to measure group social exclusion, and another grouping the other four social groups that seemed to measure personal exclusion.

Table 7

Number of Groups Excluded Labelled Personal or Group, Full Sample WVS-6 (2010-2014)

\begin{tabular}{l|r|r}
\hline Number of Groups excluded & Personal Exclusion & \multicolumn{2}{c}{ Group Exclusion } \\
\hline No group excluded & 13.8 & 59.3 \\
One excluded & 13.6 & 19.3 \\
Two excluded & 25.8 & 9.5 \\
Three excluded & 22.3 & 5.9 \\
Four excluded & 24.6 & 6.0 \\
Total & 100.0 & 100.0 \\
\hline
\end{tabular}


The construction of the two indexes has followed a similar pattern than the one used to construct the Total Social Exclusion Index. It is evident at first glance that, for the total sample of more than 85,000 respondents in the world social exclusion seems to be based more on personal or more individual characteristics (drug addicts, heavy drinkers, homosexuals and people with AIDS) than in group characteristics (different race, religion or language, and immigrants and foreign workers).

Table 8

\section{Mean Personal and Group Social Exclusion Index by Geo-Cultural Regions And Russia (Number Of Social Groups Excluded as Neighbours), WVS-6 (2010-2014)}

\begin{tabular}{l|r|r|c|r|r|r|r|r|r}
\hline Index & \multicolumn{10}{|c}{ Mean Social Exclusion } \\
\cline { 2 - 11 } & $\begin{array}{c}\text { All } \\
\text { countries }\end{array}$ & $\begin{array}{c}\text { Anglo- } \\
\text { Saxon }\end{array}$ & $\begin{array}{c}\text { European } \\
\text { Union }\end{array}$ & $\begin{array}{c}\text { East } \\
\text { Europe \& } \\
\text { Balkans }\end{array}$ & MENA & Asia & $\begin{array}{c}\text { Latin } \\
\text { America }\end{array}$ & $\begin{array}{c}\text { Sub- } \\
\text { Sahara }\end{array}$ & Russia \\
\hline Personal & $\mathbf{2 . 3 0}$ & 1.91 & 1.98 & 3.19 & 2.55 & 2.17 & 1.68 & 2.31 & $\mathbf{2 . 9 8}$ \\
Group &. $\mathbf{8 0}$ & .30 & .55 & .89 & 1.16 & 1.01 & .38 & .71 & $\mathbf{0 . 8 3}$ \\
\hline
\end{tabular}

The mean number of social groups based on personal characteristics rejected is much higher than the mean for those based on group characteristics. And once again MENA countries show one of the highest means in Personal and Group Exclusion, though East European countries have even a higher Personal Exclusion Index, and Asian countries rank second in terms of Group Exclusion. Latin American and Anglo-Saxon countries are the ones with lowest Personal and Group Exclusion. Russia, once more, shows the second highest Personal and Group Exclusion Indexes (only lower than those in East Europe and Balkan region).

\section{Describing who are the Excluders}

Following our objectives, we have described who the excluded social groups in present societies are, and then we have constructed three indexes to measure Social Exclusion. Now we must try to find out who the excluders are.

Table 9

\section{Correlation Coefficients among the three Indexes of Social Exclusion,} Full Sample WVS-6 (2010-2014)

\begin{tabular}{lr|rrr}
\hline \multicolumn{1}{c|}{ Index } & Personal Exclusion & Group Exclusion & Total Social Exclusion \\
\hline Personal Exclusion & 1 & $.190^{\star \star}$ & $.801^{\star \star}$ \\
Group Exclusion & $.190^{\star \star}$ & 1 & $.740^{\star \star}$ \\
Total Social Exclusion & $.801^{\star \star}$ & $.740^{\star \star}$ & 1 \\
\hline \multicolumn{2}{c}{${ }^{\star *}$ Correlation is significant at the .01 level (2-tailed). } & &
\end{tabular}

The three correlation coefficients are high and statistically significant, but the stronger is between Personal Exclusion and Total Exclusion, and the weakest is between Personal and Group Social Exclusion. Similar results are found in Russia, the three coefficients being statistically significant and in two cases even stronger 
than for the total sample: $r$ total vs. personal $=.769, r$ total vs. group $=.790$ and $r$ personal vs. group $=.216$.

Traditionally one would look for differences in the mean values of Social Exclusion among different segments of the population, usually demographic characteristics, in order to find out who are the groups of people who are more likely to socially exclude other groups, measured through the proxy question used in WVS surveys, and more specifically through the indexes just described. Thus Total Social Exclusion seems to be a little higher among males than among females, it is usually higher among the young ones than among the elderly, and it seems to be negatively related to education, income and employment status, with some minor exceptions. And it is certainly confirmed that in all segments of the population Personal Exclusion is higher than Group Exclusion.

But interesting as that may be, it seems more appropriate to use theoretical assumptions and try to formulate hypothesis about certain explanatory relationships. In fact, centre-periphery theory combines in a single index many of the demographic variables (Galtung, 1964, 1976; Díez-Nicolás, 1966, 2009, 2013) to measure social position of individuals in society.

Table 10

Mean Value of the three Indexes of Social Exclusion, by Some Demographic Variables, Full Sample WVS-6 (2010-2014)

\begin{tabular}{|c|c|c|c|}
\hline \multirow[t]{2}{*}{ Demographic Variables } & \multicolumn{3}{|c|}{ Indexes of Social Exclusion } \\
\hline & Personal & Group & Total \\
\hline Total & 2.30 & 0.80 & 3.11 \\
\hline \multicolumn{4}{|l|}{ Sex } \\
\hline Female & 2.31 & 0.78 & 3.09 \\
\hline Male & 2.30 & 0.82 & 3.12 \\
\hline \multicolumn{4}{|l|}{ Age groups } \\
\hline $18-29$ & 2.31 & 0.83 & 3.14 \\
\hline $30-49$ & 2.32 & 0.79 & 3.12 \\
\hline $50-64$ & 2.28 & 0.79 & 3.07 \\
\hline $65+$ & 2.27 & 0.76 & 3.03 \\
\hline \multicolumn{4}{|l|}{ Education } \\
\hline Less than primary & 2.41 & 0.93 & 3.35 \\
\hline Primary & 2.27 & 0.91 & 3.18 \\
\hline Secondary & 2.31 & 0.78 & 3.09 \\
\hline University & 2.28 & 0.69 & 2.97 \\
\hline \multicolumn{4}{|l|}{ Income } \\
\hline Low & 2.20 & 0.91 & 3.11 \\
\hline Middle Low & 2.37 & 0.78 & 3.15 \\
\hline Middle High & 2.33 & 0.77 & 3.10 \\
\hline High & 2.26 & 0.84 & 3.10 \\
\hline \multicolumn{4}{|l|}{ Employment status } \\
\hline Not employed & 2.36 & 0.85 & 3.20 \\
\hline Partial job or self employed & 2.32 & 0.89 & 3.21 \\
\hline Full time job & 2.28 & 0.70 & 2.98 \\
\hline
\end{tabular}


According to this theory some social positions are more central than others (they have more information, as well as more opinions and they generate or support new attitudes and social values earlier than the social periphery). Accordingly, individuals in the social centre should be less socially excluders than those in the social periphery. We also know that individuals in the social centre are more exposed to information than those in the social periphery, so that more individuals more exposed to information should be less socially excluders than the less exposed. For similar reasons, since the social centre is more supportive of new values (post-materialistic, more oriented towards self expression values than the social periphery, more oriented towards materialistic, survival values), we should also expect a negative relationship between post-materialist values and social exclusion (Inglehart, 1971, 1977, 1990, 1997; Díez-Nicolás, 2013). And finally, taking into account that security (in all kinds of different aspects) is becoming one of the more important values in present societies, one should expect that people who feel less secure would be more likely to be more socially excluder than those who feel more secure (Díez-Nicolás, 2015).

Therefore, we can summarize our main hypotheses as follows: social exclusion (as measured by the proxy Indexes of Social Exclusion) is negatively related to social position, to information, to post-materialist values and to perception of security. We have measurements for all five main groups of variables through different indexes. Thus, we have three measures of Social Exclusion, two of Social Position, three of Exposure to Information, one of Post-materialist values and four of Security. We have proceeded to examine these relationships before including other potential explanatory variables of Social Exclusion in a comparative world perspective and with a special focus in Russia.

The construction of the Social Position Index has followed the modification already established by Díez-Nicolás in 2009 , with full agreement by Galtung ${ }^{6}$. The distribution of the SP-5 Index in three categories (social centre, middle and social periphery is the following).

\section{Distribution of the Population in three Categories of Social Position, by Geo-Cultural Region and Russia, WVS-6 (2010-2014)}

\begin{tabular}{l|r|c|c|c|r|r|r|r|r}
\hline \multirow{2}{*}{$\begin{array}{c}\text { Categories } \\
\text { of Social } \\
\text { Position }\end{array}$} & \multicolumn{10}{|c|}{$\begin{array}{c}\text { All } \\
\text { countries }\end{array}$} & $\begin{array}{c}\text { Anglo- } \\
\text { Saxon }\end{array}$ & $\begin{array}{c}\text { European } \\
\text { Union }\end{array}$ & $\begin{array}{c}\text { East } \\
\text { Europe \& } \\
\text { Balkans }\end{array}$ & MENA & Asia & $\begin{array}{c}\text { Latin } \\
\text { America }\end{array}$ & $\begin{array}{c}\text { Sub- } \\
\text { Sahara }\end{array}$ & Russia \\
\hline Social Periphery & $\mathbf{2 2 . 7}$ & 3.5 & 13.8 & 11.9 & 34.4 & 15.1 & 19.5 & 51.1 & $\mathbf{1 3 . 4}$ \\
Middle & $\mathbf{5 4 . 5}$ & 45.2 & 51.5 & 65.0 & 52.8 & 58.5 & 56.6 & 43.9 & $\mathbf{5 9 . 8}$ \\
Social Centre & $\mathbf{1 6 . 7}$ & 37.2 & 28.3 & 21.5 & 8.0 & 19.0 & 12.2 & 3.6 & $\mathbf{2 2 . 4}$ \\
\hline
\end{tabular}

${ }^{6}$ The index is based on sex $($ male $=1$, female $=0)$; age $(-18$ and +75 years $=0 ; 18-25$ and $65-74=1$; $26-35$ and $55-64=2 ; 36-54=3$ ); educational level (less than primary =0; primary completed $=1$; secondary or technical completed = 2; university =3); income level (low = 0; middle low = 1; middle high = 2; high =3); centrality of place of residence (low = 0; middle low = 1; middle high = 2; high =3); and employment status (not employed $=0$; partial job or self employed $=1$; full time job $=2$ ). The complexity of measuring these six demographic characteristics is very high, so that some variable, like occupation or urban-rural habitat, has not been included because of lack of information or because of lack of comparability among countries. Since the correlation between the two Indexes of Social Position is $r=.95$ for all countries ( $r=.98$ for Spain), and in order to lose as little information as possible, we decided to have income for as many countries and individuals as possible, and therefore have used Social Position-6. 
As expected, the social centre is higher than the social periphery in the populations of Anglo-Saxon and European Union countries, in East European and Balkan countries and in Asia and Russia. Only in MENA and Sub-Sahara regions the social periphery is larger than the social centre. Nevertheless, the middle category is more than half the population in the total sample and all regions except Anglo-Saxon Countries and Sub-Sahara. This finding is important because if Social Position is negatively related to Social Exclusion, as has been stated as hypothesis, then we should expect more exclusionism among the populations of MENA and Sub-Saharan regions, and less in Anglo-Saxon and European Union countries.

First, we have analyzed the relationship between Social Position and Social Exclusion. The correlation matrix between the two indexes of Social Position and the three indexes of Social Exclusion shows that Social Position and Social Exclusion are negatively and statistically significantly related in all six correlation coefficients. But the three coefficients of Social Position-5 are a little stronger than with Social Position-6. And the correlation coefficients with Group Exclusion are higher than with Personal Exclusion, but negative as said before. In the case of Russia the six coefficients are negative, as expected, but the relationships are weaker, especially with SP-5. Nevertheless, for the total sample, the three correlation coefficients between SP-5 and the three social exclusion indexes are statistically significant at the .05 levels and negative, as indicated and expected, while they are significant at the .01 level for SP-6. For all these reasons we have used Social Position- 6 as the independent explanatory variable.

Table 12

\begin{tabular}{|c|c|c|c|c|c|c|c|c|c|}
\hline \multirow{2}{*}{$\begin{array}{l}\text { Indexes } \\
\text { of Social } \\
\text { Exclusion }\end{array}$} & \multicolumn{9}{|c|}{ Social position-6 Index } \\
\hline & \begin{tabular}{|c|} 
Total \\
sample \\
59 \\
countries \\
\end{tabular} & \begin{tabular}{|l|} 
Anglo- \\
Saxon
\end{tabular} & $\begin{array}{c}\text { European } \\
\text { Union }\end{array}$ & \begin{tabular}{|c|} 
East \\
Europe \& \\
Balkans
\end{tabular} & MENA & Asia & \begin{tabular}{|c|} 
Latin \\
America
\end{tabular} & \begin{tabular}{|c|} 
Sub- \\
Saharan \\
Africa
\end{tabular} & Russia \\
\hline $\begin{array}{l}\text { Personal } \\
\text { Exclusion }\end{array}$ & $-.065^{\star \star}$ & $-.089^{\star *}$ & $-.123^{\star *}$ & $-.027^{\star \star}$ & $-.018^{\star}$ & $-.081^{\star *}$ & $-.040^{\star *}$ & $-.071^{\star *}$ & $-.049^{\star}$ \\
\hline $\begin{array}{l}\text { Group } \\
\text { Exclusion }\end{array}$ & $-.087^{\star \star}$ & $-.088^{\star \star}$ & $-.100^{\star *}$ & $-.039^{* *}$ & $-.027^{\star \star}$ & $-.142^{\star \star}$ & -.018 & .007 & -.029 \\
\hline $\begin{array}{l}\text { Total } \\
\text { Exclusion }\end{array}$ & $-.098^{\star \star}$ & $-.117^{\star \star}$ & $-.140^{\star *}$ & $-.043^{\star \star}$ & $-.028^{\star \star}$ & $-.151^{\star \star}$ & $-.040^{\star *}$ & $-.048^{\star \star}$ & $-.050^{*}$ \\
\hline
\end{tabular}

* Correlation is significant at the .05 level (2-tailed).

${ }^{\star *}$ Correlation is significant at the .01 level (2-tailed).

It may be observed that the relationship of Social Position- 6 with the three Social Exclusion Indexes is negative in all geo-cultural regions and Russia, like in the total sample, with the only exceptions of the relationship with Group Exclusion in Latin America and Sub-Saharan countries. And all relationships are statistically significant at the .05 level and most at the .01 level, with the previous exceptions plus the relationship with Group Exclusion in Russia. People in the 
social periphery are therefore more likely to be social exclusionists, especially personal exclusionists, than people in the social centre, a finding that is coherent with centre-periphery theory.

The second hypothesis refers to exposure to information. In this case we have constructed four indexes. The WVS survey had information about recent exposure to daily newspapers, printed magazines, TV news, radio news, mobile phone, e-mail, internet and talk with friends, a total of eight sources of information. We constructed a first general Index of Information by adding one point for each source to which the respondent had been exposed recently. But then we decided to construct two separate indexes, one for Traditional Information sources (daily newspapers, printed magazines, TV news and radio news), and a second one for New Social Media (mobile phone, e-mail, internet and talk with friends). Furthermore, we constructed an additional Traditional Information Index excluding exposure to TV.

Most respondents all over the world use regularly between three and five media, in a distribution that looks very much as a "normal" distribution, with only $2 \%$ who admit they don't use any media at all, and $7 \%$ who declare using the eight media regularly. But there are significant differences on the use of media in different geocultural regions of the world.

Table 13

Mean and Standard Deviation in Information Indexes by Geo-Cultural Regions and Russia (Number of Media Used Last Week), WVS-6 (2010-2014)

\begin{tabular}{|c|c|c|c|c|c|c|c|c|c|}
\hline $\begin{array}{l}\text { Mean and } \\
\text { Standard } \\
\text { Deviation }\end{array}$ & $\begin{array}{c}\text { All } \\
\text { countries }\end{array}$ & $\begin{array}{l}\text { Anglo- } \\
\text { Saxon }\end{array}$ & $\begin{array}{c}\text { European } \\
\text { Union }\end{array}$ & \begin{tabular}{|c|} 
East \\
Europe \& \\
Balkans \\
\end{tabular} & MENA & Asia & $\begin{array}{c}\text { Latin } \\
\text { America }\end{array}$ & $\begin{array}{l}\text { Sub- } \\
\text { Sahara }\end{array}$ & Russia \\
\hline \multicolumn{10}{|c|}{ Information index 3} \\
\hline$\overline{\mathrm{x}}$ & 4.29 & 4.88 & 5.17 & 4.12 & 3.99 & 4.21 & 4.22 & 3.82 & 4.37 \\
\hline$\sigma$ & 2.03 & 1.92 & 1.95 & 1.83 & 2.08 & 2.11 & 1.91 & 1.95 & 1.88 \\
\hline \multicolumn{10}{|c|}{ Social networks use index } \\
\hline$\overline{\bar{x}}$ & 2.03 & 2.49 & 2.45 & 1.86 & 2.11 & 1.92 & 1.92 & 1.67 & 2.05 \\
\hline$\sigma$ & 1.38 & 1.35 & 1.40 & 1.25 & 1.42 & 1.40 & 1.40 & 1.22 & 1.35 \\
\hline \multicolumn{10}{|c|}{ Traditional media use index } \\
\hline$\overline{\bar{x}}$ & 2.26 & 2.40 & 2.72 & 2.26 & 1.88 & 2.28 & 2.30 & 2.15 & 2.32 \\
\hline$\sigma$ & 1.10 & 1.10 & 1.08 & 1.06 & 1.06 & 1.12 & 1.01 & 1.10 & 1.05 \\
\hline \multicolumn{10}{|c|}{ Traditional media use index (excluding TV) } \\
\hline$\overline{\bar{x}}$ & 1.37 & 1.55 & 1.79 & 1.32 & 1.02 & 1.38 & 1.37 & 1.41 & 1.39 \\
\hline$\sigma$ & .99 & 0.92 & .99 & 1.01 & 0.94 & 1.03 & 0.93 & 0.85 & 0.98 \\
\hline
\end{tabular}

As expected, use of all types of media, new social networks or traditional media, is higher in the more developed world, that is, European Union and Anglo-Saxon countries, and lower in MENA region and Sub-Saharan countries. It must be observed that the use of new social networks is lower in Latin American and Asian countries than in MENA region countries, while the opposite is true regarding traditional media (even if one takes out use of TV). Probably this indicates that new social networks or media had a very significant role in MENA region countries in recent years (since 2010 onwards), because their index of use is higher than in all other regions and Russia, apart 
from Anglo-Saxon and European Union countries. Russians use media very regularly, since their Information index is only lower than in Anglo-Saxon and European Union countries, its use of New Social Media is only lower than those two regions plus MENA region, and it ranks third after Anglo-Saxon and European Union countries regarding the use of traditional media, even if TV is not taken into consideration.

All correlation coefficients among the four indexes of information are statistically significant at the .01 level, not only for the total sample of 59 countries, but also for the seven geo-cultural regions and Russia. The relationships are rather strong, especially between the general Information Index-3 and the index of use of new social networks media.

Table 14

\section{Correlation Coefficients between Information Indexes and Social Exclusion} Indexes, Full Sample WVS-6 (2010-2014)

\begin{tabular}{l|r|r|r}
\hline \multicolumn{1}{c|}{ Index } & $\begin{array}{c}\text { Information } \\
\text { index-3 }\end{array}$ & $\begin{array}{c}\text { New Social Media } \\
\text { Use Index }\end{array}$ & $\begin{array}{c}\text { Traditional Media } \\
\text { Use Index }\end{array}$ \\
\hline Total Social Exclusion Index & $-.062^{\star *}$ & $-.043^{* *}$ & $-.063^{\star *}$ \\
Personal Exclusion Index & $-.055^{\star *}$ & $-.033^{* *}$ & $-.060^{\star *}$ \\
Group Exclusion Index & $-.041^{\star *}$ & $-.033^{\star *}$ & $-.037^{\star *}$ \\
\hline
\end{tabular}

${ }^{* *}$ Correlation is significant at the .01 level (2-tailed).

The initial hypothesis on the relationship between information and social exclusion is confirmed, in the sense that it is negative, so that respondents more informed are less likely to be socially exclusionists and vice versa. We have decided to use Information Index-3 to measure the total exposure to information.

Table 15

Correlation Coefficients between Information Index-3 and three Indexes of Social Exclusion, by Geo-Cultural Region and Russia, WVS-6 (2010-2014)

\begin{tabular}{|c|c|c|c|c|c|c|c|c|c|}
\hline \multirow[t]{2}{*}{ Exclusion } & \multicolumn{9}{|c|}{ Information index-3 } \\
\hline & \begin{tabular}{|c|} 
Total \\
sample \\
59 \\
countries
\end{tabular} & $\begin{array}{l}\text { Anglo- } \\
\text { Saxon }\end{array}$ & $\begin{array}{c}\text { European } \\
\text { Union }\end{array}$ & $\begin{array}{c}\text { East } \\
\text { Europe } \\
\& \\
\text { Balkans }\end{array}$ & MENA & Asia & \begin{tabular}{|l} 
Latin \\
America
\end{tabular} & \begin{tabular}{|c|} 
Sub- \\
Saharan \\
Africa
\end{tabular} & Russia \\
\hline $\begin{array}{l}\text { Personal Social } \\
\text { Exclusion }\end{array}$ & $-.055^{\star \star}$ & ${ }^{*} .000$ & $-.090^{\star \star}$ & $-.063^{* *}$ & $.067^{\star \star}$ & $-.098^{\star *}$ & .006 & -.008 & -.031 \\
\hline $\begin{array}{l}\text { Group Social } \\
\text { Exclusion }\end{array}$ & $-.041^{* *}$ & -.016 & $-.027^{\star \star}$ & $-.069^{\star \star}$ & -.012 & -.008 & -.006 & $.047^{\star \star}$ & .000 \\
\hline $\begin{array}{l}\text { Total Social } \\
\text { Exclusion }\end{array}$ & $-.062^{\star \star}$ & -.009 & $-.076^{\star \star}$ & $-.085^{\star \star}$ & $.038^{\star *}$ & $-.077^{\star *}$ & .001 & $.030^{\star *}$ & -.020 \\
\hline
\end{tabular}

${ }^{\star \star}$ Correlation is significant at the .01 level (2-tailed).

But the relationship does not hold for Anglo-Saxon and Latin American countries, neither for Russia, in any of the three indexes of social exclusion. It doesn't hold either for group exclusion in MENA region and Asia, or for personal exclusion in Sub-Sahara. And more surprisingly, the relationship is positive and not negative, but statistically significant for group and total social exclusion in Sub-Saharan countries. 
The lack of full confirmation of the relationship between exposure to information and social exclusion deserves more analysis in the future regarding the regions involved, but the relationship is confirmed in most regions and for the three indexes of social exclusion.

However, and according to the theory, the relationship between social position and information is strongly positive and statistically significant at the 0.01 level, implying that the social centre uses much more than the social periphery all types of media, traditional or new social networks. The relationship is positive, strong and statistically significant at the .01 level in the nine coefficients, in all seven regions and also in Russia.

The third hypothesis refers to the values system. According to the theory new post-materialistic values are positively related with social position and with information, and therefore should be negatively related to social exclusion. That is, people oriented towards new post-materialistic, self-expression values, should be less exclusionist of any social groups than people oriented towards the more survival, conservative and traditional values. Inglehart developed two indexes, one with 12 items and another one with only four items (two measuring materialism and two measuring post-materialist attitudes). The four items index has proven to be much better predictor in all countries, and it is the one we use here (Díez-Nicolás, 2000).

Table 16

Percent Distribution of the Population by Values, by Geo-Cultural Regions and Russia, WVS-6 (2010-2014)

\begin{tabular}{l|r|r|r|r|r|r|r|r|r}
\hline \multicolumn{1}{c|}{ Values } & $\begin{array}{c}\text { All } \\
\text { countries }\end{array}$ & $\begin{array}{c}\text { Anglo- European } \\
\text { Saxon }\end{array}$ & $\begin{array}{c}\text { East } \\
\text { Union } \\
\text { Europe \& } \\
\text { Balkans }\end{array}$ & MENA & Asia & $\begin{array}{c}\text { Latin } \\
\text { America }\end{array}$ & $\begin{array}{c}\text { Sub- } \\
\text { Saharan } \\
\text { Africa }\end{array}$ & Russia \\
\hline Materialist & $\mathbf{3 4 . 2}$ & 19.1 & 25.3 & 49.0 & 38.9 & 34.0 & 23.9 & 37.4 & $\mathbf{5 2 . 7}$ \\
Mixed & $\mathbf{5 2 . 0}$ & 56.3 & 58.4 & 45.3 & 44.4 & 52.1 & 57.3 & 57.4 & $\mathbf{4 1 . 8}$ \\
Post-materialist & $\mathbf{8 . 2}$ & 16.9 & 12.7 & 2.8 & 5.1 & 7.0 & 14.8 & 5.0 & $\mathbf{2 . 1}$ \\
Total & $\mathbf{9 4 . 3}$ & 92.3 & 96.4 & 97.1 & 88.4 & 93.2 & 96.0 & 99.8 & $\mathbf{9 6 . 6}$ \\
Missing; Unknown & $\mathbf{5 . 7}$ & 7.7 & 3.6 & 2.9 & 11.6 & 6.8 & 4.0 & .2 & $\mathbf{3 . 4}$ \\
\hline
\end{tabular}

Usually more than half the population in each territory shows mixed values, materialist and post-materialist, and the proportion of materialists is generally higher than the proportion of post-materialists. As may be observed, all distributions are very similar (a very frequent finding when using this scale), but the proportion of the population oriented towards the new post-materialist values is a little higher in Anglo-Saxon and European Union countries, as well as in Latin America. And it is extremely low in East Europe and the Balkans, and even lower in Russia.

Correlation Coefficients between Post-Materialist Values

Table 17

\begin{tabular}{|c|c|}
\hline Index & Post-materialist index (4-item) \\
\hline Personal Exclusion Index & $-.134^{\star \star}$ \\
\hline Group Exclusion Index & $-.036^{\star \star}$ \\
\hline Total Social Exclusion Index & $-.113^{\star \star}$ \\
\hline
\end{tabular}


The relationship between post-materialist values and social exclusion is negative and statistically significant at .01 level, as expected from the theory. New post-materialistic values include tolerance and social acceptance of people who are different. Therefore, those with post-materialistic values are expected not to be social excluders.

Table 18

Correlation Coefficients between Post-Materialism-4 and three Indexes of Social Exclusion, by Geo-Cultural Region and Russia, WVS-6 (2010-2014)

\begin{tabular}{|c|c|c|c|c|c|c|c|c|c|}
\hline \multirow[t]{2}{*}{ Exclusion } & \multicolumn{9}{|c|}{ Post-materialism-4 } \\
\hline & \begin{tabular}{|c|} 
Total \\
sample \\
59 \\
countries
\end{tabular} & \begin{tabular}{|l|} 
Anglo- \\
Saxon
\end{tabular} & \begin{tabular}{|c|} 
European \\
Union
\end{tabular} & $\begin{array}{c}\text { East } \\
\text { Europe } \\
\& \\
\text { Balkans }\end{array}$ & MENA & Asia & $\begin{array}{c}\text { Latin } \\
\text { America }\end{array}$ & $\begin{array}{c}\text { Sub- } \\
\text { Saharan } \\
\text { Africa }\end{array}$ & Russia \\
\hline Personal & $-.134^{\star *}$ & $-.065^{\star \star}$ & $-139 * *$ & $-.040^{\star \star}$ & $-.018^{\star}$ & $-.116^{\star \star}$ & $-.053^{\star \star}$ & $-.029^{\star \star}$ & -.018 \\
\hline Group & $-.036^{\star *}$ & $-.040^{\star \star}$ & $-.093^{\star *}$ & $.038^{* *}$ & $.055^{\star *}$ & -.003 & .013 & $.048^{\star \star}$ & $.050^{*}$ \\
\hline Total & $-.113^{\star *}$ & $-.070^{\star \star}$ & $-.147^{\star \star}$ & .002 & $.020^{\star}$ & $-.086^{\star \star}$ & $-.030^{\star *}$ & .015 & .021 \\
\hline
\end{tabular}

${ }^{*}$ Correlation is significant at the .05 level (2-tailed).

${ }^{* *}$ Correlation is significant at the .01 level (2-tailed).

The three coefficients are generally negative and statistically significant in most regions, with only two a few exceptions on the significance, usually regarding the relationship with group or total exclusion. There are also some exceptions regarding the sign of the relationship in East Europe and the Balkans, in MENA region, in Latin America, in Sub-Sahara and in Russia.

Confirming also the theory, there is a positive and statistically significant relationship of Social Position and Information with Post-materialist values, implying that people in the social centre and those very much exposed to information tend to be more oriented towards the new post-materialistic values, while the less informed and in the social periphery are more oriented towards survival and traditional values. And this is true in all regions and in Russia, with only one exception: Anglo-Saxon countries and only regarding the relationship between social position and post-materialism.

The fourth and final hypothesis regards the relationship of Perception of Security and Social Exclusion. In previous research we have explained why Security has become one of the most important values (Díez-Nicolás, 2011, 2015). Perception of Security has been measured at four levels, personal (that includes family), community and national or external, plus total that summarizes the first three.

Mean Perception of Total Perceived Security (Scale 1 to 4) by Geo-Cultural Regions and Russia, WVS-6 (2010-2014)

\begin{tabular}{l|r|c|c|c|c|c|c|c|c}
\hline $\begin{array}{c}\text { Perceived } \\
\text { Security }\end{array}$ & $\begin{array}{c}\text { All } \\
\text { countries }\end{array}$ & $\begin{array}{c}\text { Anglo- } \\
\text { Saxon }\end{array}$ & $\begin{array}{c}\text { Unionean } \\
\text { Union }\end{array}$ & $\begin{array}{c}\text { East } \\
\text { Europe \& } \\
\text { Balkans }\end{array}$ & MENA & Asia & $\begin{array}{c}\text { Latin } \\
\text { America }\end{array}$ & $\begin{array}{c}\text { Sub- } \\
\text { Saharan } \\
\text { Africa }\end{array}$ & Russia \\
\hline Personal & $\mathbf{2 . 0 8}$ & 2.80 & 2.60 & 2.10 & 2.03 & 1.96 & 1.84 & 1.73 & $\mathbf{2 . 3 3}$ \\
Community & $\mathbf{3 . 1 6}$ & 3.28 & 3.46 & 3.26 & 3.21 & 3.37 & 2.64 & 2.86 & $\mathbf{2 . 6 9}$ \\
National & $\mathbf{2 . 1 8}$ & 2.81 & 2.80 & 2.02 & 1.83 & 2.15 & 2.14 & 1.92 & $\mathbf{2 . 0 6}$ \\
Total & $\mathbf{2 . 5 2}$ & 2.98 & 2.99 & 2.50 & 2.36 & 2.56 & 2.25 & 2.24 & $\mathbf{2 . 3 6}$ \\
\hline
\end{tabular}


Perception of community security seems to be higher than personal and national security in all regions and also in Russia. Perception of all kinds of security is higher in Anglo-Saxon and European Union countries than in any other region. Perception of security in Russia is lower than in those two regions, but higher than in any other region with respect to Personal Security. But, regarding Community Security Russia scores lower than any region except Latin America. National Security in Russia is only higher than in East Europe and Balkans, MENA region and Sub-Saharan countries. And Total Security in Russia is only higher than in Latin America and Sub-Saharan countries. The lowest perception of personal security and total security is found in Sub-Saharan countries, but the lowest perception of community security is found in Latin America, probably due to organized crime in some countries like Mexico and some other countries, but countries in MENA region are the ones that show the lowest perception of national or external security, an expected finding given the conflictive situation of the region because of violence in Syria, Iraq, Afghanistan, etc.

All correlation coefficients of the four indexes of security among themselves are high and statistically significant, implying that the four aspects seem to be overlapping. But total perception of security shows the strongest relationships with the other three indexes. This is also true in each of the seven regions, and in Russia.

Correlation Coefficients among the four Indexes of Perceived Security Table 20 and Social Exclusion, Full Sample WVS-6 (2010-2014)

\begin{tabular}{l|r|r|r|r}
\hline \multicolumn{1}{c|}{ Exclusion } & $\begin{array}{c}\text { Standardized } \\
\text { Total Security } \\
\text { Index }\end{array}$ & $\begin{array}{c}\text { Standardized } \\
\text { Personal } \\
\text { Security Index }\end{array}$ & $\begin{array}{c}\text { Standardized } \\
\text { Community } \\
\text { Security Index }\end{array}$ & $\begin{array}{c}\text { Standardized } \\
\text { External } \\
\text { Security Index }\end{array}$ \\
\hline Personal Social Exclusion & $-.048^{\star \star}$ & $-.058^{\star *}$ & $.087^{\star \star}$ & $-.101^{\star \star}$ \\
Group Social Exclusion & $-.064^{\star \star}$ & $-.035^{\star *}$ & $.020^{\star \star}$ & $-.090^{\star \star}$ \\
Total Social Exclusion & $-.072^{\star *}$ & $-.061^{\star *}$ & $.071^{\star *}$ & $-.124^{\star *}$ \\
\hline
\end{tabular}

${ }^{\star *}$ Correlation is significant at the .01 level (2-tailed).

Our initial hypothesis about a negative relationship between perception of security and social exclusion is confirmed. People who feel secure do not fear other different peoples. All the correlation coefficients are negative and statistically significant at the .01 level, with the only exceptions of perceived community security, which shows a positive correlation with all three indexes of social exclusion. We decided to use Perceived Total Security as a predictor, since it includes the other three indicators.

Table 21

Correlation Coefficients between Total Perceived Security and three Indexes of Social Exclusion, by Geo-Cultural Region and Russia, WVS-6 (2010-14)

\begin{tabular}{|c|c|c|c|c|c|c|c|c|c|}
\hline \multirow[t]{2}{*}{ Exclusion } & \multicolumn{9}{|c|}{ Total perceived security } \\
\hline & $\begin{array}{c}\text { Total } \\
\text { sample } 59 \\
\text { countries }\end{array}$ & $\begin{array}{l}\text { Anglo- } \\
\text { Saxon }\end{array}$ & $\begin{array}{c}\text { European } \\
\text { Union }\end{array}$ & $\begin{array}{c}\text { East } \\
\text { Europe \& } \\
\text { Balkans }\end{array}$ & MENA & Asia & $\begin{array}{c}\text { Latin } \\
\text { America }\end{array}$ & $\begin{array}{c}\text { Sub- } \\
\text { Saharan } \\
\text { Africa }\end{array}$ & Russia \\
\hline Personal & $-.048^{* *}$ & $-.051^{\star *}$ & $-.080^{\star *}$ & .000 & $.057^{\star \star}$ & $-.037^{\star \star}$ & * $-.058^{\star \star}$ & ${ }^{\star}-.046^{\star *}$ & -.011 \\
\hline Group & $-.064^{\star \star}$ & $-.079^{\star *}$ & $-.076^{\star \star}$ & -.004 & $.092^{\star *}$ & $-.109^{\star *}$ & $-.111^{\star \star}$ & -.007 & -.056 \\
\hline Total & $-.072^{\star *}$ & $-.084^{\star *}$ & $-.097^{\star \star}$ & -.002 & $.093^{\star *}$ & $-.099^{* *}$ & * $-.109^{\star *}$ & ${ }^{*}-.040^{\star *}$ & * -.044 \\
\hline
\end{tabular}

${ }^{\star *}$ Correlation is significant at the .01 level (2-tailed). 
In general, the relationships are negative and significant, with only a few exceptions. For example, total perception of security does not seem to be significantly related to any of the three measures of social exclusion in East European and Balkan countries and coherently in Russia. There seems to be no relationship either between total perceived group exclusion in Sub-Saharan countries. But it must be pointed out that even in those cases the relationship between perceived security and social exclusion is generally negative.

We may then summarize our main findings, and especially the results of our main hypotheses about how social position, exposure to information, values and perception of security may affect social exclusion. For each of the four predictors we have selected the index that seems to give a more global measurement of each concept.

Table 22

Correlation Coefficients between Total Social Exclusion and Social Position-6, Information-3, Post-Materialist Values-4, and Total Perception of Security, by Geo-Cultural Region and Russia, WVS-6 (2010-2014)

\begin{tabular}{|c|c|c|c|c|c|c|c|c|c|}
\hline \multirow[t]{2}{*}{ Index } & \multicolumn{9}{|c|}{ Total Social Exclusion Index } \\
\hline & \begin{tabular}{|c|} 
All \\
countries
\end{tabular} & $\begin{array}{l}\text { Anglo- } \\
\text { Saxon }\end{array}$ & $\begin{array}{c}\text { European } \\
\text { Union }\end{array}$ & \begin{tabular}{|c|} 
East \\
Europe \& \\
Balkans \\
\end{tabular} & MENA & Asia & $\begin{array}{c}\text { Latin } \\
\text { America }\end{array}$ & \begin{tabular}{|c|} 
Sub- \\
Saharan \\
Africa
\end{tabular} & Russia \\
\hline $\begin{array}{l}\text { Social Position } \\
\text { Index-6 }\end{array}$ & $-.098^{\star *}$ & $-.117^{\star *}$ & $-.140^{\star *}$ & $-.043^{\star *}$ & $-.028^{\star \star}$ & $-.151^{\star \star}$ & $-.040^{\star \star}$ & $-.048^{\star \star}$ & $-.050^{*}$ \\
\hline $\begin{array}{l}\text { Information } \\
\text { Index-3 }\end{array}$ & $-.062^{\star *}$ & -.009 & $-.076^{\star *}$ & $-.085^{\star \star}$ & $.038^{\star *}$ & $-.077^{\star *}$ & .001 & $.030^{\star *}$ & -.020 \\
\hline $\begin{array}{l}\text { Post- } \\
\text { materialist-4 } \\
\text { index }\end{array}$ & $-.113^{\star *}$ & $-.070^{\star \star}$ & $-.147^{\star \star}$ & .002 & $.020^{*}$ & $-.086^{\star *}$ & $-.030^{* *}$ & .015 & .021 \\
\hline $\begin{array}{l}\text { Total Security } \\
\text { Index }\end{array}$ & $-.072^{\star *}$ & $-.084^{\star *}$ & $-.097^{\star *}$ & -.002 & $.093^{\star *}$ & $-.099^{\star \star}$ & $-.109^{\star \star}$ & $-.040^{\star \star}$ & -.044 \\
\hline
\end{tabular}

${ }^{*}$ Correlation is significant at the .05 level (2-tailed).

${ }^{* *}$ Correlation is significant at the .01 level (2-tailed).

We have supplied enough evidence to confirm our initial hypotheses, in the sense that Social Position, Information, Post-materialist values, and Perception of Security are negatively related to Social Exclusion. Most correlation coefficients adjust to the described pattern, that is, they are negative and statistically significant. But the data for MENA region and Sub-Saharan countries seem not to support entirely these hypotheses, and partially that is also true in East Europe and the Balkans, in Russia and in Latin America. However, data from Anglo-Saxon, European Union and Asian countries support fully our hypotheses. More analysis is needed to find out why some relationships are a little different in some regions.

\section{Explaining Social Exclusion}

The four independent, explanatory variables, that have been analyzed, probably contribute to the explanation of social exclusion in different societies around the world, more in some countries than in others. It seems now the time to establish 
how much they explain, and whether or not there are other variables that may contribute to expand the degree that social exclusion can be explained. From the analysis of correlation coefficients one might conclude that values, that is, postmaterialist values, would be the variable that contributes more to the explanation of social exclusion. But we also know that the four variables analyzed as explanatory variables are quite related among themselves.

Therefore, it seems necessary first to establish how much the four of them together can explain, and how much each one of them contributes to the explanation.

\begin{tabular}{|c|c|c|c|c|c|c|c|c|c|}
\hline \multicolumn{10}{|c|}{$\begin{array}{l}\text { Table } 23 \\
\text { Regression Model for Explaining Total Social Exclusion on the Basis } \\
\text { of Social Position, Information-3, Post-Materialism-4 and Total Perceived } \\
\text { Security, by Geo-Cultural Region and Russia, WVS-6 (2010-2014) } \\
\text { Variables }\end{array}$} \\
\hline Variables & \begin{tabular}{|c|} 
All \\
countries
\end{tabular} & \begin{tabular}{|l|} 
Anglo- \\
Saxon
\end{tabular} & \begin{tabular}{|c|} 
European \\
Union
\end{tabular} & \begin{tabular}{|c|} 
East \\
Europe \& \\
Balkans
\end{tabular} & MENA & Asia & $\begin{array}{c}\text { Latin } \\
\text { America }\end{array}$ & \begin{tabular}{|c|} 
Sub- \\
Sahara
\end{tabular} & Russia \\
\hline $\mathrm{R}^{2}$ adjusted $=$ & $.022^{\star *}$ & * $.023^{\star \star}$ & $.041^{\star \star}$ & $.015^{\star \star}$ & ${ }^{*} .020^{\star *}$ & $.035^{\star \star}$ & $.005^{\star \star}$ & $.007^{* *}$ & .005 \\
\hline \multicolumn{10}{|c|}{ Standardized Beta Coefficients } \\
\hline $\begin{array}{l}\text { Social } \\
\text { Position-6 }\end{array}$ & $-.074^{\star *}$ & * $-.110^{\star *}$ & $-.119^{* *}$ & * $\quad-.040^{* *}$ & * -.011 & $-.116^{\star \star}$ & * $-.025^{\star}$ & $-.067^{\star *}$ & -.061 \\
\hline Information-3 & $-.028^{\star *}$ & .019 & -.004 & $-.110^{\star *}$ & * $.082^{* *}$ & $-.025^{\star}$ & .024 & $.065^{\star *}$ & .001 \\
\hline $\begin{array}{l}\text { Post- } \\
\text { materialism-4 }\end{array}$ & $-.089^{\star *}$ & ${ }^{*}-.062^{\star \star}$ & $-.117^{\star \star}$ & .009 & $.066^{\star *}$ & $-.079^{\star \star}$ & ${ }^{\star} \quad-.025^{\star}$ & .017 & .047 \\
\hline Total Security & $-.051^{\star *}$ & ${ }^{*}-.082^{\star \star}$ & $-.085^{\star *}$ & -.016 & $.104^{\star *}$ & $-.119^{\star *}$ & $-.068^{* *}$ & $-.035^{\star *}$ & -.051 \\
\hline
\end{tabular}

The model explains only $2 \%$ of the total variance in Total Social Exclusion for the total sample of 59 countries and more than 85,000 respondents, and the relationship is significant at the .01 level. As may be seen, all four indexes are negatively related to Social Exclusion, confirming our initial hypotheses that the higher the social position, the higher the exposure to information, the higher the post-materialism and the higher the perception of security, the lower would be the number of social groups not wanted as neighbours. When the model is calculated for the seven regions, it is observed that the adjusted total regression coefficient ( $R^{2}$ adjusted) is higher in European Union countries and Asia, and lower in Latin American and Sub-Saharan countries. It is also very low and statistically not significant in Russia. Nevertheless, most adjusted regression coefficients (beta) are negative and statistically significant, as expected. But there are two types of results that do not follow the general expected pattern. Some relationships are positive instead of negative, and some coefficients, regardless of their direction, are not statistically significant. The first type of deviation is found mainly in MENA region countries, and the second type is in most cases related to the relationship of information with social exclusion. In the case of Russia none of the four coefficients is statistically significant.

Post-materialism and Social Position seem to be the two variables that contribute more to the explanation of Total Social Exclusion in the total sample. 
But there are many differences when looking at the regression coefficients in each region. Social Position and Post-materialism are the two variables that explain more in European Union countries. Social position is the best predictor in Anglo-Saxon and Sub-Saharan countries, Information is the best in East Europe and the Balkans, Total Perceived Security and Social Position are the best in Asia, and Total Perceived Security is the explanatory variable that contributes more to the explanation of Total Social Exclusion in Latin America. As we said, a great variety and not one single pattern, which means that the region, and even more, the country, continues to be the most useful unit of analysis. In any case, these results suggest that it would be appropriate to look for additional variables that, according to previous research, and especially, according to the variables available in the combined data set of European and World Values research, and to the potential capacity to explain that they have shown in other pieces of research on values, are expected to increase the percent of the variance explained by the model.

Table 24

\section{Regression Model for Explaining Total Social Exclusion on the Basis of a Group of Explanatory Variables, by Geo-Cultural Region and Russia, WVS-6 (2010-2014)}

\begin{tabular}{|c|c|c|c|c|c|c|c|c|c|}
\hline \multirow{2}{*}{$\begin{array}{l}\text { Explanatory } \\
\text { variables }\end{array}$} & \multicolumn{9}{|c|}{ Total social exclusion } \\
\hline & \begin{tabular}{|c|} 
All \\
countries
\end{tabular} & $\begin{array}{l}\text { Anglo- } \\
\text { Saxon }\end{array}$ & $\begin{array}{c}\text { European } \\
\text { Union }\end{array}$ & \begin{tabular}{|c|} 
East \\
Europe \& \\
Balkans
\end{tabular} & MENA & Asia & \begin{tabular}{|c|} 
Latin \\
America
\end{tabular} & $\begin{array}{c}\text { Sub- } \\
\text { Sahara }\end{array}$ & Russia \\
\hline $\mathrm{R}^{2}$ adjusted $=$ & $.052^{\star \star}$ & $.056^{\star \star}$ & $.068^{\star \star}$ & $.055^{\star \star}$ & $\star .026$ ** & * $.052^{\star \star}$ & $.030^{\star *}$ & * $.014^{\star *}$ & .018 \\
\hline \multicolumn{10}{|c|}{ Standardized Beta Coefficients } \\
\hline $\begin{array}{l}\text { Social } \\
\text { Position-6 }\end{array}$ & $-.040^{\star *}$ & $-.087^{\star \star}$ & $-.077^{\star *}$ & -.025 & -.004 & $-.142^{\star \star}$ & -.004 & $-.065^{\star \star}$ & * -.057 \\
\hline Information-3 & $-.018^{\star *}$ & .023 & .028 * & $-.080^{\star *}$ & ${ }^{\star}-.043^{* *}$ & * -.005 & $.043^{* *}$ & * $.054^{\star *}$ & .050 \\
\hline $\begin{array}{l}\text { Post- } \\
\text { materialism-4 }\end{array}$ & $-.089^{\star \star}$ & $-.038 *$ & $-.102^{\star \star}$ & .004 & $.063^{\star *}$ & ${ }^{\star}-.101^{\star *}$ & -.011 & .020 & .045 \\
\hline $\begin{array}{l}\text { Total Perception } \\
\text { of Security }\end{array}$ & $-.040^{\star \star}$ & -.031 & $-.051^{\star *}$ & .023 & -.002 & $-.113^{\star \star}$ & $-.040^{\star \star}$ & ${ }^{\star}-.044^{\star *}$ & * -.053 \\
\hline $\begin{array}{l}\text { Feeling of } \\
\text { happiness }\end{array}$ & $-.029^{\star \star}$ & -.011 & $-.053^{\star \star}$ & .001 & .003 & $-.046^{\star *}$ & -.010 & -.010 & -.004 \\
\hline $\begin{array}{l}\text { Self-evaluation } \\
\text { of health }\end{array}$ & $-.015^{\star \star}$ & -.016 & $-.031^{*}$ & .019 & .011 & $.057^{\star *}$ & $-.052^{\star \star}$ & .020 & -.059 \\
\hline $\begin{array}{l}\text { Satisfaction } \\
\text { with life }\end{array}$ & $-.085^{\star \star}$ & $-.093^{\star \star}$ & $-.051^{\star *}$ & $-.117^{\star \star}$ & * -.004 & -.009 & $-.049^{* *}$ & .007 & -.032 \\
\hline Ideology & $.056^{\star \star}$ & $.159^{\star \star}$ & $.062^{\star *}$ & .015 & $.040^{\star \star}$ & * .004 & .030 * & ${ }^{\star}-.033^{\star *}$ & * -.021 \\
\hline $\begin{array}{l}\text { Importance } \\
\text { of democracy }\end{array}$ & $-.061^{\star \star}$ & $-.045^{\star \star}$ & $-.057^{\star \star}$ & $-.038^{\star \star}$ & ${ }^{\star}-.079^{\star \star}$ & $\star \quad .008$ & $-.065^{\star \star}$ & ${ }^{\star}-.038^{\star \star}$ & * -.091 \\
\hline $\begin{array}{l}\text { Religious } \\
\text { person }\end{array}$ & $-.014^{*}$ & $.065^{\star *}$ & $.040^{*}$ & $-.112^{\star \star}$ & $.053^{\star *}$ & .000 & $.075^{\star \star}$ & * $.029^{* *}$ & .096 \\
\hline $\begin{array}{l}\text { Importance } \\
\text { of God in life }\end{array}$ & $.091^{\star *}$ & -.007 & $.073^{\star \star}$ & $.156^{\star *}$ & .001 & -.021 & -.017 & $.069^{* \star}$ & ${ }^{*}-.120^{\star *}$ \\
\hline National pride & $-.033^{\star \star}$ & .008 & .011 & $-.069^{\star \star}$ & $-.111^{\star \star}$ & ${ }^{\star}-.061^{\star \star}$ & $-.107^{\star \star}$ & $.028^{\star}$ & .373 \\
\hline
\end{tabular}

* Correlation is significant at the .05 level (2-tailed).

${ }^{\star *}$ Correlation is significant at the .01 level (2-tailed). 
We have therefore constructed a regression model to explain total social exclusion with the same four independent variables and eight additional ones ${ }^{7}$. This model explains $5 \%$ of the variance in Total Social Exclusion, more than twice what was explained by the model with the four explanatory variables. But there is a high degree of variation regarding the proportion of the variance explained in the different regions. We may observe that the model explains more in European Union countries (7\%) and very little in Sub-Saharan and MENA countries (1\% and $3 \%$ respectively). The model explains almost $2 \%$ of the variance in total social exclusion in Russia, even much less than in the East Europe and Balkans region.

The important finding is that, in spite of the possible relationships between each variable and the other eleven, all the variables contribute to the explanation of Total Social Exclusion in a statistically significant manner in the total sample. The variables that seem to contribute more to the explanation of Total Social Exclusion, in the total sample, are the importance of God in their life (positively), post-materialism and satisfaction with life, (both of them negatively related). Those who say that God is not important in their life, the post-materialists and the satisfied with their life are less likely to be exclusionists.

In Anglo-Saxon countries, the variable that contributes the most is ideology, but the relationship is not negative but positive, which means that individuals who consider themselves in the right are more likely to be exclusionists. The same would apply to self-evaluation as a religious person; those who consider themselves religious are more likely to be exclusionists. However, social position and satisfaction with life do contribute negatively and significantly to explain Total Social Exclusion (those in the social centre and those who are satisfied are likely not to be exclusionists).

In European Union countries post-materialism and social position are the best predictors of Total Social Exclusion, and in a lesser degree also importance of democracy, feeling of happiness, perceived security and satisfaction with life, all of them negatively related to Total Social Exclusion. But importance of God in their life and ideology are positively and significantly related to the dependent variable.

In East Europe and the Balkans satisfaction with life and being a religious person are the variables that contribute the most to the explanation of Total Social Exclusion, and less but always in a negative and significant manner, information, national pride and importance of democracy. But importance of God in their life is related positively to Total Social Exclusion, so that those for whom God is more important tend to be exclusionists.

In MENA region countries only six variables contribute the most to explain Total Social Exclusion, in order from more to less, national pride, importance of democracy and information (negatively) and post-materialism, being a religious person and ideology (positively).

In Asia, social position, perceived security and post-materialism are the best predictors of Total Social Exclusion, but also national pride, self-evaluation of health

${ }^{7}$ Feeling of happiness (4 categories), self-evaluation of health (4 categories), satisfaction with life (10 categories), the self positioning in the ideological scale (7 categories), importance of democracy (10 categories), self-evaluation of religiosity (3 categories), importance of God in one's life (10 categories), and national pride (4 categories). 
and feeling of happiness. All of them are negatively related to the dependent variable except self-evaluation of health, which means that those who think they are in good health are more likely to be exclusionists.

In Latin America, national pride is the best predictor of Total Social Exclusion, so that those who are very proud of being nationals of their country are likely to be less exclusionists. Other significant negative relationships are importance of democracy, self-evaluation of health, satisfaction with life and total perceived security. But those who consider themselves to be religious and who are very exposed to information tend to be more likely to be exclusionists. Social position, perceived security, importance of democracy and ideology are the variables that in Sub-Saharan countries contribute more to the explanation of Total Social Exclusion, all of them in a negative direction. But importance of God in their life, being a religious person and information contribute positively to that explanation.

Finally, only one variable contributes significantly to explain Total Social Exclusion in Russia: Importance of God in their life, meaning that Russians who answer that God is important in their life tend to be less exclusionist ${ }^{8}$.

We have constructed a second regression model to explain personal social exclusion with the same twelve independent variables. This model explains also $5 \%$ of the variance in personal social exclusion. The model explains more in Asian countries and in European Union countries (6\%) and very little in Latin America and MENA countries ( $2 \%$ and $3 \%$ respectively), and even less in Russia. The variation among regions is therefore quite less than regarding total social exclusion. All of the twelve variables contribute to the explanation of personal social exclusion in a statistically significant manner in the total sample, except the self evaluation as a religious person. The variables that contribute most to the explanation of the variance in personal social exclusion, in the total sample, are the importance of God in their life, and post-materialism, but with different directions, positively in the first case and negatively in the second. This finding is basically the same than was found regarding Total Social Exclusion.

When examining the relationships of the independent variables with the dependent one, personal social exclusion, it is evident that most are similar to what was found with respect to total social exclusion. In order not to repeat the same comments, we only comment which are the variables that contribute more to the explanation of the variance of the dependent variable. Thus, in Anglo-Saxon countries that variable is ideology (positively related with personal social exclusion), but in Sub-Saharan countries the same variable is the best predictor, though the relationship is negative. In European Union countries the best predictor is postmaterialism, negatively related to the dependent variable. In East Europe and the

${ }^{8}$ The fact that a variable does not contribute to the explanation of social exclusion does not mean that it is not related to the dependent variable, it only means that it does not add anything to the explanation over what other variables have already explained, probably due to its relationships with these other variables. We want to insist on this issue because too frequently some analysts will come to the conclusion that the specific independent variable is not related to the dependent variable. The fact is that it doesn't add anything to what other variables explain, but we don't know really what would be the case if the said variables were not present. 
Balkans, and in Asia, importance of God in life is the variable that contributes more to the explanation of the variance in personal social exclusion, in the sense that those for whom God is very important are likely to be exclusionists. National pride and information are negatively related to personal social exclusion as the best predictors of its variance in MENA region countries. Being a religious person is positively related to personal social exclusion in Latin America, and is the variable that contributes more to explaining its variance. And finally, none of the independent variables seem to contribute significantly to the explanation of Personal Exclusion in Russia.

The third regression model includes the same twelve independent variables to explain the variance in group social exclusion. This model only explains a $3 \%$ of that variance, that is, a little more than half what the previous two models explain. The variation among regions is therefore less than regarding total or personal social exclusion, from 3\% in Latin America and Sub-Saharan Africa to 7\% in Asia. However, the model explains 4\% of the variance in Group Exclusion in Russia, and in this case this finding is highly statistically significant (at the .01 level).

Eight of the twelve variables contribute to the explanation of group social exclusion in a statistically significant manner in the total sample. The variable that contributes most to the explanation of the variance in group social exclusion, in the total sample, is importance of democracy. This finding is quite different to what was found in the previous two models. It implies that those who don't consider democracy important tend to be more exclusionists.

When examining the relationships of the independent variables with the dependent one, group social exclusion, it is evident that most are similar to what was found with respect to total and to personal social exclusion. In order not to repeat the same comments, we will only comment which are the variables that contribute more to the explanation of the variance of the dependent variable. Thus, in Anglo-Saxon countries that variable is again ideology (positively related with group social exclusion). In European Union and Asian countries the best predictor is social position, negatively related to the dependent variable. In East Europe and the Balkans three variables contribute more to the explanation of the variance in group social exclusion, two negatively (importance of democracy and religiosity), and one positively related (importance of God in their life). But in Russia religiosity is the best predictor of Group Exclusion, in the sense that those who consider themselves more religious tend to be also more exclusionist. Importance of democracy is negatively related to group social exclusion as the best predictor of its variance in MENA region countries. Importance of God in one's life (plus social position mentioned above) is negatively related to group social exclusion in Asia, and they are the variables that contribute more to explaining its variance. National pride is negatively related to group social exclusion as its best predictor.

\section{Conclusions and Discussion of Results}

This research paper has been based almost exclusively on the World Values Survey data file of the $6^{\text {th }}$ wave, conducted in 59 countries with a total of more than 85,000 
personal interviews collected almost entirely through face-to-face interviews at the home of the respondent ${ }^{9}$.

Based on the evidence presented here we can conclude that drug addicts, heavy drinkers, homosexuals and people with AIDS are the four more undesired social groups as neighbours worldwide. The only exceptions are that Immigrants are more undesired than people with AIDS in Sub-Saharan countries.

Two main reasons could explain why drug-addicts score first in all geo-cultural regions. On the one hand, excluders manifest fear of them linking drug-addiction with crime and poverty. On the other hand, people tend to blame drug-addicts, heavydrinkers, people with AIDS for an allegedly voluntary behaviour. March, OviedoJoekes, and Romero (2006) conclude that, despite the diversity of characteristics between countries, socially excluded drug users showed high scores in specific exclusion indicators, such as incarceration, illegal drug use, housing problems, poor health status, lack of employment, and engagement in criminal activities. According to Seddon (2006), Santana (2002), and Foster (2000), the problem of drug-related crime is inextricably linked with issues of socio-economic disadvantage and social exclusion.

The association of drugs with criminality and poverty has come to be seen as natural rather than historically novel. Pearson (1989) suggests that this is part of a wider process of the social construction of drug problems, which, as observes, has tended historically to focus on the drug consumption of socially disadvantaged groups. Mathiesen (1990), Bauman (1998), and Wacquant (2001) consider that there is a "criminalization of the poor" as criminal law and penal responses tend to focus most on the activities of the socially and economically disadvantaged. For Foucault (1991), Healy (2001), and Voruz (2005), this relation has come to be an objective and unquestionable truth that invariably begins as a response to a concrete situation which is "real" but that also offers scope for a more radical critical account that can destabilise the present.

Alcoholism is a severely stigmatized condition, which is heavily associated with a notion of blame and enforcement of social norms. Furthermore, alcohol-dependent persons are seen as unpredictable and dangerous and alcoholism is seen as a voluntary condition. Negative stereotypes like being dangerous or unpredictable cannot simply be rejected as being wrong, as drunken driving and alcohol-related domestic violence are societal problems. Phelan et al. (2008) argue that in those diseases presenting as a deviant but voluntary behaviour, the purpose of stigmatization could be enforcement of social norms. The function of stigma and prejudice may be to make the deviant conform and rejoin the in-group, or it may be to clarify for other group members the boundaries for acceptable behaviour and identity and the consequences for nonconformity. Schomerus, Lucht, Holzinger, Matschinger, Carta, and Angermeyer (2011) concluded that compared with people suffering from other, substance-unrelated mental disorders, alcohol-dependent persons are less frequently regarded as mentally ill, are held much more responsible for their condition, provoke more social rejection and more negative emotions, and are at particular risk for structural discrimination. Their conclusion is that alcoholism is a particularly severely stigmatized mental disorder.

${ }^{9}$ Retrieved from: www.worldvaluessurvey.org 
Bayer (2008) and Burris (2008) think that, seen from a perspective of purpose, the question arises whether stigmatization of alcoholism could not simply represent a rational, successful strategy to improve public health, forcing people to cut down their drinking to avoid stigmatization. Drinking per se, however, is not stigmatized. On the contrary, drinking alcohol is a social behaviour that is often associated with inclusion in a social grouping; it may even be a signal of power and status (Room, 2005), and often, even heavy drinking is socially accepted behaviour, examples are wedding receptions, business meetings and parties. Thus, when a person's drinking behaviour violates these norms and evokes stigmatization, the drinking problem has presumably become quite severe.

Taken together with the results from Ethiopia, a country with a low per capita alcohol consumption (Rehm et al., 2009), which depict alcoholism as a comparatively less exclusionary condition there, the question arises whether alcoholism may be generally less stigmatized in societies with lower alcohol consumption like many Islamic countries or India (Rehm et al., 2009), or to what extent the stigma of alcoholism depends on cultural belief systems about health and illness in general (Mulatu, 1999). For Santana (2002), alcohol has been shown to be responsible for a substantial burden of disease in Europe and other established market economies, especially in the area of morbidity and disability, as well as in terms of substantial social costs. For De Toledo, Piza Peluso, and Blay (2008) individuals with alcohol dependence are perceived as violent and capable of arising negative reactions among members of the community, such as negative ideas and reactions of avoidance and distancing.

Scott (1998) observed that attitudes towards homosexuality were becoming slowly more tolerant, especially among women, but condemnation of extramarital sex remained high. She concluded that religion played an important role in explaining within and cross-national variations in attitudes and that provided a powerful counterbalance to permissiveness trends. Changing attitudes to sexual morality were not as revolutionary as claimed and the demise of traditional values was over-stated. Simmons (2008) has developed an analysis on the ways in which immigration and homosexuality are jointly produced and regulated by the state through immigration policy. Cross-national surveys suggest that negative attitudes toward homosexuality are more prevalent in the new Europe (Štulhofer \& Sandfort, 2005; Inglehart \& Welzel, 2005).

Among the new members of the EU and the other post-communist countries, the Eastern Orthodox countries were found higher in homo negativity than the Roman Catholic. A similar finding was reported by Inglehart and Welzel (2005), who used the WVS database. In comparison to the Protestant and Catholic religion, Eastern Orthodoxy increases social distance toward homosexuals, regardless of the level of modernization.

Exposure to a diversity of ideas and people that is typically associated with university education encourages people to be more open-minded and liberal (Inglehart, 1977). As economic prosperity increases through modernization, a change in citizens' value systems also occurs. According to Inglehart and his collaborators (Inglehart, 1971, 1977, 1990, 1997; Inglehart \& Norris, 2003; Inglehart \& Welzel, 2003, 2004), a shift from materialist to post-materialist values, or self-expression values, takes 
place when chances to satisfy material needs increase. Materialist values include the following: satisfying economic living conditions, security, national identity and the exclusion of outsiders. Post-materialist or self-expression values, in contrast, are characterized by the desire for self-fulfilment, an emphasis on freedom, participation and the tolerance of diversity (Inglehart, 2006). Inglehart interprets discrimination against homosexuals as one type of social exclusion. He shows that existential security tends to make all out-groups, including homosexuals, more acceptable.

Main results for Russia show that drug addicts and heavy drinkers are not desired as neighbours, their rejection has increased in the last two waves. Attitudinal studies in Russia have highlighted pervasive stigma directed toward both people with HIV and people who inject drugs (Balanova et al., 2006; Lioznov \& Nikolaenko, 2011). Additionally, according to a Policy Briefing by WHO European Centre for Environment and Health (2006), there is considerable evidence which supports links between drinking and violent behavior. In the Russian Federation, alcohol consumption has been noted to be involved in the perpetration of violence generally as well as in specific types of violence.

Homosexuals are excluded by almost two thirds of Russian respondents since 1995 , though a little less than they were in 1990. This is coherent with conclusions by Gulevich et al. (2016) who suggest that negative attitudes toward homosexuals include a perception of threat originating from homosexuals viewed as an active group. Individuals with high levels of prejudice see homosexuality as a deviation from a natural and moral norm that may threaten social morals, unless it is contained. Homosexuality is seen as a fashion, based on Western influence, which threatens Russian values. Homosexuals are perceived as a source of threat to individuals (as they are believed to be inclined to molest children and "convert" "normal" heterosexual adults to homosexual ways) and to the Russian society as a whole.

\section{Summary of Main Results}

The first main finding is that social exclusion of the same groups seems to be very stable across time and space, with very few changes between 1981 and 2010, and very few differences comparing seven geo-cultural world regions. Through principal component analysis it was found that apparently people all over the world, with very few exceptions, perceive two different types of social groups, those to which individuals belong regardless of their own personal decision (immigrants and foreign workers, different race, religion or language), and those who apparently have at least partially done something to belong to (drug addicts, heavy drinkers, people with AIDS and homosexuals). Results have been analyzed through seven geo-cultural regions in which the 59 countries have been distributed. Russia has been analyzed also separately. It has been found that social groups based on more individual choice are more excluded than those to which individuals belonged not because of their choice.

An index of total social exclusion has been constructed based on the number of social groups mentioned by respondents as undesired neighbours, ranging from 0 to 8 points. This total exclusion index has been disaggregated into two components, the personal exclusion index and the group exclusion index, each based on the exclusion 
of four social groups respectively. All the indexes have been calculated for the total sample of 59 countries, the 7 geo-cultural regions and Russia. On the basis of these three indexes we have identified what categories of persons are more or less likely to be excluders. For that purpose different statistical tools have been used, mainly descriptive. Finally, an attempt to explain the main factors that lead to social exclusion has been implemented, mainly through correlation and regression analysis. Thus, it was confirmed that the four main explanatory variables: social position, information, post-materialist values and perception of security are negatively related to social exclusion because of existing theory and previous research. Other explanatory variables were added, measuring social, economic, political and religious attitudes and behaviours, which increased the power to explain social exclusion. But results show that social position, post-materialist values and some religious indicators seem to be the variables that contribute more to the explanation of social exclusion, though there are important specifications in these relationships in the different geo-cultural regions. Main findings are coherent with existing theory and research in this topic.

\section{References}

Adorno, T.W., Frenkel-Brunswik, E., Levinson, D. J., \& Sanford, R. N. (1950). The Authoritarian Personality. New York: Harper \& Row.

Allport, G. (1954). The Nature of Prejudice. Reading, MA: Addison-Wesley.

Balabanova, Y., Coker, R., Atun, R. A., \& Drobniewski, F. (2006). Stigma and HIV infection in Russia. AIDS Care, 18(7), 846-852.

Bauman, Z. (1998). Globalization: The Human Consequences. Cambridge, UK: Polity Press.

Baumgarten, I. (2006). Interpersonal Violence and Alcohol in the Russian Federation. Policy Briefing. Violence and Injury Prevention Programme WHO European Centre for Environment and Health.

Bayer, R. (2008). Stigma and the ethics of public health: not can we but should we. SocSci Med, 67, 463-472. DOI: 10.1016/j.socscimed.2008.03.017.

Burgess, E.W. (1984). Can Neighborhood have a Scientific Basis? In: Janowitz M. (Ed.). The heritage of Sociology. The City. Suggestions for Investigation of Human Behavior. Chicago: The University of Chicago Press.

Burris, S. (2008). Stigma, ethics and policy: a commentary on Bayer's "Stigma and the ethics of public health: Not can we but should we". SocSci Med, 67, 473-475, discussion 476-477. DOI: 10.1016/i.socscimed.2008.03.020.

Clark, W. A. V. (1986). Residential segregation in American cities: a review and interpretation. Population Research and Policy Review, 5(2), 95-127.

Clark, W.A.V. (2006). Ethnic Preferences and Residential Segregation: A Commentary on Outcomes from Agent-Based Modelling. The Journal of Mathematical Sociology, 30(3-4). DOI: 10.1080/00222500500544128.

Deacon, H., Stephney, I., \& Prosalendis, S. (2005). Understanding HIV/AIDS Stigma. A Theoretical and Methodological Analysis. HSRC Research Monograph, 
Research Programmes on Social Cohesion and Identity \& The Social Aspects of HIVI AIDS and Health. Cape Town: HSRC Press.

De La Garza, M., \& Valdés, M. C. (1998): Teoría e Historia de las Religiones. México, DF: Facultad de Filosofia y Letras UNAM.

De Toledo Piza Peluso, E., \& Blay, S.L. (2008). Public perception of alcohol dependence. A percepção popular sobre a dependência alcoólica. Revista Brasileira de Psiquiatria, 30(1). DOI: 10.1590/S1516-44462008000100004.

Díez-Nicolás, J. (1966). Posición Social y Opinión Pública. Anales de Sociología, No. 2, Barcelona.

Díez-Nicolás, J. (2000). La Escala de Postmaterialismo como Medida del Cambio de Valores en las Sociedades Contemporáneas. In F. A. Orizo and J. Elzo (Eds.). España 2000, entre el Localismo y la Globalidad. La Encuesta Europea de Valores en su Tercera Aplicación, 1981-1999. Madrid: Editorial SM.

Díez-Nicolás, J. (2009). Some Theoretical and Methodological Applications of Centre-Periphery Theory and the Social Position Index. In K. van der Veer, A. Hartmannn, H. van den Berg (Eds.) and J. Díez-Nicolás, J. Galtung and H. Wiberg, Multidimensional Social Science, Amsterdam: Rozenberg.

Díez-Nicolás, J. (2011). La Seguridad Subjetiva en España: Construcción de un Índice Sintético de Seguridad Subjetiva. Madrid: Ministerio de Defensa.

Díez-Nicolás, J. (2013). Sociological Theory and Social Reality. Revista Española de Investigaciones Sociológicas, 143, Madrid: CIS.

Díez-Nicolás, J. (2015). Perception of security in an international comparative perspective". Real Instituto Elcano. Working Paper, 16/2015. Retrieved from: www. realinstitutoelcano.org

Eliade, M. (1961). Traité d'Histoire des Réligions. Paris: Ed. Payot.

Elliot, G.C., Ziegler, H.L., Altman, B.M., \& Scott, D.R. (1982). Understanding stigma: Dimensions of deviance and coping. Deviant Behaviour, 3, 275-300.

Figueira, T.J. (1987). Residential Restrictions on the Athenian Ostracized. Greek, Roman and Byzantine Studies, 28(3), 281-305.

Forsdyke, S. (2000). Exile, Ostracism and the Athenian Democracy. Classical Antiquity, 19(2), 232-263. DOI: 10.2307/25011121.

Fosset, M. (2006). Including Preference and Social Distance Dynamics in MultiFactor Theories of Segregation. The Journal of Mathematical Sociology, 30(3-4). DOI: 10.1080/00222500500544151.

Fosset, M. (2011). Generative Models of Segregation: Investigating ModelGenerated Patterns of Residential Segregation by Ethnicity and Socioeconomic Status. The Journal of Mathematical Sociology. 35(1-3). DOI: 10.1080/0022250X.2010.532367.

Foster, J. (2000). Social Exclusion, Crime and Drugs. Drugs: Education, Prevention and Policy, 7 (4). DOI: 10.1080/dep.7.4.317.330.

Foucault, M. (1991). Questions of Method. In G. Burchell, C. Gordon \& P. Miller, (Eds.). The Foucault Effect: Studies in Govern mentality. Hemel Hempstead: Harvester Wheatsheaf. 
Galtung, J. (1964). Foreign policy opinion as a function of social position. Journal of Peace Research, 34, 206-231.

Galtung, J. (1976). Social position and the image of the future. In H. Ornauer et al. (Eds.). Images of the World in the Year 2000. Paris: Mouton.

Glaster, G. (2001). On the Nature of Neighbourhood. Urban Studies, 38(12), 2111-2124. DOI: $10.1080 / 00420980120087072$.

Glass, R. (1964). Introduction: aspects of change. In Centre for Urban Studies (Ed.) Aspects of Change. London: Mac Kibbon and Kee.

Goffman, E. (1963). Stigma: Notes on the Management of Spoiled Identity. New York, NY: Simon \& Schuster.

Gulevich, O.A., Osin, E. N., Isaenko, N.A., \& Brainis, L. M. (2016). Attitudes to Homosexuals In Russia: Content, Structure, and Predictors. Psychology Journal of the Higher School of Economics, 13(1), 79-110.

Healy, P. (2001). A 'Limit Attitude': Foucault, Autonomy, Critique. History of the Human Sciences, 14, 49-68.

Inglehart, R. (1971). The Silent Revolution in Europe. American Political Science Review, 65, 991-1017.

Inglehart, R. (1977). The Silent Revolution: Changing Values and Political Styles among Western European Publics. Princeton, NJ: Princeton University Press.

Inglehart, R. (1990). Cultural Shift in Advanced Industrial Society. Princeton, NJ: Princeton University Press.

Inglehart, R. (1997): Modernization and Postmodernization: Cultural, Economic, and Political Change in 43 Societies. Princeton, NJ: Princeton University Press.

Inglehart, R. (2006). Changing Norms: Existential Security Leads to Growing Acceptance of Out-Groups. WZB-Mitteilungen, 113, 26-29.

Inglehart, R., \& Baker, W.E. (2000). Modernization, Cultural Change, and the Persistence of Traditional Values. American Sociological Review, 65, 19-51.

Inglehart, R., \& Norris, P. (2003). The True Clash of Civilizations. Foreign Policy, March/April: 67-74.

Inglehart, R., \& Welzel, C. (2003). Political Culture and Democracy: Analyzing Cross-Level Linkages. Comparative Politics, 36, 61-81.

Inglehart, R., \& Welzel, C. (2004). Modernization, Cultural Change and Democracy: The Human Development Sequence. Cambridge: Cambridge University Press.

Inglehart, R., \& Welzel, C. (2005). Modernization, cultural change, and democracy. Cambridge: Cambridge University Press.

Joffe, H. (1996). AIDS Research and Prevention: A Social Representational Approach. British Journal of Medical Psychology, 69(3), 169-190.

Joffe, H. (1999). Risk and "the Other". Cambridge: Cambridge University Press.

Levitas, R. (2005). The inclusive society? Social exclusion and New Labour ( $2^{\text {nd }}$ ed.) Basingstoke: Palgrave Macmillan. 
Lioznov, D., \& Nikolaenko, S. (Eds). (2011). HIV-related stigma among intravenous drug users in St. Petersburg, Russia. Presented at $6^{\text {th }}$ International AIDS Society Conference on HIV Pathogenesis, Treatment and Prevention, Rome, Italy.

Macy, M.W., \& Van De Rijt, A. (2006). Ethnic Preferences and Residential Segregation: Theoretical Explorations Beyond Detroit. The Journal of Mathematical Sociology, 30(3-4). DOI: 10.1080/00222500500544086.

Mandanipour, A. (2016). Social Exclusion and Space. Chapter 4. In R. T. Le Gates \& F. Stout (Eds.), Urban Reader Series: The City Reader. Abingdon, Oxon, UK: Routledge.

March, J.C., Oviedo-Joekes, E., \& Romero, M. (2006). Drugs and Social Exclusion in Ten European Cities. Eur Addict Res, 12, 33-41.

Marcuse, P. (1985). Gentrification, Abandonment, and Displacement: Connections, Causes, and Policy Responses in New York City. Retrieved from: http://openscholarship.wustl.edu/law urbanlaw/vol28/iss1/4

Mathiesen, T. (1990). Prison on Trial: A Critical Assessment. London: Sage.

Mulatu, M.S. (1999). Perceptions of Mental and Physical Illnesses in Northwestern Ethiopia: Causes, Treatments, and Attitudes. Journal of Health Psychology. 4(4), 531-49. DOI: 10.1177/135910539900400407.

Park, R.E., \& Burgess, R. [1925] (1984). The City. Suggestions for the investigation of human behaviour in the urban environment. In R. Park \& R. Burgess (Eds.), The City. Chicago: University of Chicago Press.

Parker, R., \& Aggleton, P. (2003). HIV/AIDS-related stigma and discrimination: A conceptual framework and an agenda for action. Social Science \& Medicine, 57, 13-24.

Pearson, G. (1989). Heroin Use in its Social Context. In D. Herbert \& D. Smith (Eds.), Social Problems and the City. Oxford: Oxford University Press.

Phelan, J.C., Link, B.G., \& Dovidio, J.F. (2008). Stigma and prejudice: One animal or two? Social Science \& Medicine, 67(3), 358-367. DOI: 10.1016/j. socscimed.2008.03.022.

Rehm, J., Mathers, C., Popova, S., Thavorncharoensap, M., Teerawattananon, Y., \& Patra, J. (2009). Global burden of disease and injury and economic cost attributable to alcohol use and alcohol-use disorders. The Lancet, 373(9682). DOI: 10.1016/ S0140-6736(09)60746-7.

Rodgers, G., (1995). What is special about a social exclusion approach? In G. Rodgers, C. Gore \& J.B. Figueiredo (Eds.). Social Exclusion: Rhetoric, Reality, Responses. (pp. 43-55). Geneva: International Labour Organization.

Room, G. et al. (1992). Observatory on national policies to combat social exclusion. In: Second annual report. Brussels: Directorate General for Employment, Social Affairs and Industrial Relations, Commission of the European Communities.

Room, G. (1995). Poverty and social exclusion: the new European agenda for policy and research. In G. Room (Ed.). Beyond the threshold. The measurement and analysis of social exclusion. Bristol: Policy Press. 
Room, R. (2005). Stigma, social inequality and alcohol and drug use. Drug and Alcohol Review, 24(2), 143-155. DOI: 10.1080/09595230500102434.

Santana, P. (2002). Poverty, social exclusion and health in Portugal. Social Science \& Medicine, 55, 33-45.

Sassen, S. (2005). Introduction. In: Y. Kazepov (Ed.). Cities of Europe. Changing Contexts, Local Arrangements, and the Challenge to Urban Cohesion. Malden, MA: Blackwell Publishing.

Sayce, L. (2000). From Psychiatric Patient to Citizen: Overcoming Discrimination and Social Exclusion. Basingstoke: Macmillan.

Schelling, T.C. (1971). Dynamic models of segregation. Journal of Mathematical Sociology, 1, 143-186.

Schomerus, G., Lucht, M., Holzinger, A., Matschinger, H., Carta, M.G., \& Angermeyer M.C. (2011). The Stigma of Alcohol Dependence Compared with Other Mental Disorders. A Review of Population Studies. Alcohol, 46(2), 105-112. DOI: 10.1093/alcalc/agq089.

Scott, J. (1998). Changing Attitudes to Sexual Morality: A Cross-National Comparison. Sociology, 32(4), 815-845.

Seddon, T. (2006). Drugs, Crime and Social Exclusion: Social Context and Social Theory. British Journal of Criminology, 46(4), 680-703. DOI: 10.1093/bjc/ azi079.

Sen, A. (1992). Poverty Re-examined. Cambridge, MA: Harvard University Press.

Simmons, T. (2008). Sexuality and immigration: UK family reunion policy and the regulation of sexual citizens in the European Union. Political Geography, 27, 213-230.

Spitko, E.G. (2012). Don't Ask, Don't Tell: Employment Discrimination as a Means for Social Cleansing. Retrieved from: http://digitalcommons.law.scu.edu/ facpubs/573

Štulhofer, A., \& Sandfort, T. (2005). Sexuality and gender in post communist Eastern Europe and Russia. New York: Haworth Press.

United Nations (2014). World's population increasingly urban with more than half living in urban areas. Retrieved from: http://www.un.org/en/development/desa/ news/population/world-urbanization-prospects-2014.html

Voruz, V. (2005). The Politics of the Culture of Control: Undoing Genealogy. Economy and Society, 34, 154-72.

Wacquant, L. (2001). The Penalization of Poverty and the Rise of Neo-Liberalism. European Journal on Criminal Policy and Research, 9, 401-412.

Woods, R. A. (1913). The Neighbourhood in Social Reconstruction. Papers and Proceedings of the Eight Annual Meeting of the American Sociological Society.

Zick, A., Küpper, B., \& Hövermann, A. (2011). Intolerance, Prejudice and Discrimination. A European Report. Berlin: Nora Langenbacher Friedrich-EbertStiftung, Forum Berlin, Projekt "Auseinan der setzung mit dem Rechts extremismus". 